\title{
Sea, sickness and cautionary tales: a multi-isotope study from a post-mediaeval hospital at the city-port of Gibraltar (AD 1462-1704)
}

\author{
Emma Lightfoot ${ }^{1}$ (D) Emma Pomeroy ${ }^{2}$ (D) - Jennifer Grant ${ }^{3} \cdot$ Tamsin C. O'Connell $^{2}$ (D) Petrus le Roux ${ }^{4}$ (D) \\ Sonia Zakrzewski ${ }^{5} \cdot$ Sarah Inskip $^{1}$ (D) - Sam Benady ${ }^{6} \cdot$ Clive Finlayson $^{7} \cdot$ Geraldine Finlayson $^{7} \cdot$ Kevin Lane $^{8}$ (D)
}

Received: 12 February 2020 / Accepted: 7 October 2020 / Published online: 9 November 2020

(C) The Author(s) 2020

\begin{abstract}
During the sixteenth to eighteenth centuries, Spanish ships sailed around the globe connecting Spain to its colonies. While documentary records offer rich details concerning life on board ship, archaeological information is essential to generating a full picture of the past. The cemetery at Old St Bernard's Hospital, Gibraltar, provides an opportunity to study the skeletal remains of sailors. Following previous osteological research, carbon, nitrogen, oxygen and strontium isotope analyses were undertaken on thirty-three of these individuals. The results show that the, largely male, individuals had various different diets during life and came from several different places. Diets were largely based on $\mathrm{C}_{3}$ food chains; some individuals consumed $\mathrm{C}_{3}$ foods with low $\delta^{13} \mathrm{C}$ values; others consumed some marine foods, and a few individuals had a high trophic level diet, through the consumption of either freshwater resources or a high proportion of animal protein. The individuals spent their childhoods in several different places, although these homelands do not correlate simply with dietary variation. This variety in diets and homelands is consistent with our expectations for this hospital site given its location in a post-mediaeval entrepôt. The interpretation of these results are greatly helped by the available historical information and this has broader implications for the interpretation of isotope data elsewhere where the historical context of the site and the mobility patterns of the individuals are less well known.
\end{abstract}

Keywords Palaeodiet $\cdot$ Mobility $\cdot$ Collagen $\cdot$ Enamel $\cdot$ Hospital

\section{Introduction}

During the sixteenth to eighteenth centuries Spanish ships sailed around the globe transporting cargo, such as agricultural goods and precious metals, to mainland Spain from

Supplementary Information The online version of this article (https:// doi.org/10.1007/s12520-020-01220-0) contains supplementary material, which is available to authorized users.

Emma Lightfoot

ELFL2@cam.ac.uk

1 McDonald Institute for Archaeological Research, University of Cambridge, Downing Street, Cambridge CB2 3ER, UK

2 Department of Archaeology, University of Cambridge, Downing Street, Cambridge CB2 3DZ, UK

3 Consejo Nacional de Investigaciones Científicas y Técnicas (CONICET), Instituto Nacional de Antropología y Pensamiento Latinoamericano (INAPL), 3 de Febrero 1378, 1426 Ciudad Autónoma de Buenos Aires, Argentina overseas colonies and Spanish goods, such as ceramics, oil and books, in the opposite direction. Vital to this trade were the sailors themselves. While documentary records offer rich details concerning life on board ship, from the routes travelled to religious practices, archaeological information offers

4 Department of Geological Sciences, University of Cape Town, Rondebosch 7700, South Africa

5 Archaeology, University of Southampton, Highfield, Southampton SO17 1BF, UK

6 Gibraltar Heritage Trust, John Mackintosh Square, Gibraltar, Gibraltar

7 The Gibraltar National Museum, Bomb House Lane 18-20, Gibraltar

8 Instituto de Arqueología, Universidad de Buenos Aires, Buenos Aires, Argentina 
evidence not covered in these sources and is essential to generating a more nuanced picture of the past.

The site analysed in this study, now referred to as 'Old St Bernard's Hospital', Gibraltar, offers a rare chance to analyse the skeletal remains of sailors. Here we present the results of carbon $\left(\delta^{13} \mathrm{C}\right)$, nitrogen $\left(\delta^{15} \mathrm{~N}\right)$, oxygen $\left(\delta^{18} \mathrm{O}\right)$ and strontium $\left({ }^{87} \mathrm{Sr} /{ }^{86} \mathrm{Sr}\right)$ isotope analyses undertaken on thirty-three individuals (largely identified as young adult males) in order to further elucidate their lives, in particular the variability in their diets and homelands.

In addition, these data present an opportunity to discuss broader difficulties in interpreting isotopic data for palaeodietary and mobility reconstruction. Some of these issues are methodological and well-established (for example: the turnover time of bone collagen; the difficulty of establishing a relevant faunal palaeodietary baseline and the problem of using strontium to identify migrants in the absence of an established basemap and small-scale strontium isotopic variation), while others relate to the site itself (particularly the complex mobility patterns of the studied individuals) but are only known because the site is part of a well-documented, post-mediaeval entrepôt. These latter issues will also apply in other temporal and geographical settings where the historical background of the site and mobility patterns of the individuals are less clear.

\section{Background}

\section{Historical background and archaeological context}

Gibraltar is located on the southern coast of the Iberian Peninsula, at a strategic crossroads between Africa and Europe, the Atlantic and the Mediterranean. In 1462, it was taken by the Duke of Medina Sidonia and passed to the Spanish Crown in 1501. After this time, it served as a garrisoned entrepôt linking Spain to its colonies and the wider world. For two centuries, increasing prosperity attracted merchants, soldiers and religious orders, the latter of whom established churches, chapels and hospitals (Hernández del Portillo 2008; Gozalbes Busto 1997; Ballesta Gómez 2008)). A hospital was initially established at the site now known as Old St Bernard's Hospital in 1567 by Juan Mateos, a prosperous merchant (Benady 1994) primarily to treat mariners (Hernández del Portillo 2008 [1610-22]); by 1591, it was run by the Order of (San) Juan de Dios. It operated until the Anglo-Dutch conquest of 1704.

The hospital was located on the western side of the Rock of Gibraltar at c. $40 \mathrm{~m}$ above sea level. Excavations in 2014 uncovered the remains of 251 individuals. This likely underestimates the original number of burials, given that the area had been impacted post-burial by infrastructure works. Some burials were arranged in small groups of two to five, while others appear to have been individual burials. The majority of the individuals were approximately extended supine and orientated either east-west or north-south, broadly consistent with Christian burial practices of this time. Very few grave goods were found in association with the graves (Pomeroy et al. 2018). Osteological analyses indicate that the majority of individuals were male, and that the burials of infants, children and young adolescents were rare (Online Resource 1; Pomeroy et al. 2018). This was consistent with a hospital cemetery associated with the treatment of sailors.

Eight radiometric dates for the site exist, four of which are presented here for the first time (6 human and 2 ovis/capra; Table 1). Of the two ovis/capra dates, one (OxA-35081: 374 \pm 23 unCal BP) with an anomalous early date of AD $1339 \pm$ 54 , can be excluded as a closer examination of the context from which it was taken, suggests that the bone was intrusive, incorporated into the grave fill from domestic contexts located below the cemetery level (Pomeroy et al. 2018). The remaining seven dates generally cluster between the mid- 15 th and the early 17 th century; this rather wide chronological bracket ( $\sim 150-180$ years) is related to known problems with the IntCal13 calibration curve at this chronological juncture (Reimer et al. 2013). The existing historical data and archaeological material remains allow us to disregard the 15th and early 16 th century range of the dates as the extant material culture in association with the bodies found onsite dates almost exclusively to the Spanish Early Modern Period (1550 1650) (Pomeroy et al. 2018). Coupled with documentary evidence that the hospital was founded in 1567 , we have a potential terminus post quem for the cemetery. Regarding an end date for the hospital, AD 1640 would seem to be the figure around which four of the dates coalesce. Therefore, we would seem to have a maximum chronology of use for the cemetery which spans approximately 70 years (AD 15671640). This means that during the latter part of the 17th century, when the site still functioned as a Spanish hospice, it was no longer being used as a cemetery.

\section{Origins and diet of Spanish seafarers}

The vast majority of Spanish sailors at this time came from humble origins, although generals, admirals, captains and their adjuncts were members of the lower nobility (PérezMallaína 2005). Documentary evidence suggests foreigners made up approximately $20 \%$ of Spanish crews around this time, of which 50\% were Portuguese, 25\% Italian and the remainder split between 'levantiscos' (likely from the Levant or eastern Mediterranean, although sometimes referring to the east coast of Spain), Flemish and Germans (Pérez-Mallaína 2005). In reality, the proportion of foreign sailors was probably much higher than $20 \%$, as origins were concealed in order to avoid legal limitations on the proportion of foreign sailors (Pérez-Mallaína 2005). Approximately 90\% of the Spanish component of the crew was recruited from Andalusia and 
Table 1 Radiocarbon dates from the St. Bernard's Hospital excavation. Calibration was undertaken using Oxcal v4 3.2 Bronk Ramsey (2017) and the r5 IntCal13 Atmospheric Curve (Reimer et al. 2013)

\begin{tabular}{|c|c|c|c|c|c|c|c|c|}
\hline \multirow[t]{2}{*}{$\begin{array}{l}\text { Radiocarbon Date } \\
\text { [Lab: OxCal] }\end{array}$} & \multirow[t]{2}{*}{ Uncalibrated Date (BP) } & \multirow[t]{2}{*}{$\begin{array}{l}\text { Sample Identification } \\
{[\text { Ind = individual }]}\end{array}$} & \multicolumn{3}{|c|}{$\begin{array}{l}\text { Calibrated Date at 2-Sigma } \\
\text { standard deviation }(\mathrm{AD})\end{array}$} & \multicolumn{3}{|c|}{$\begin{array}{l}\text { Calibrated Date at 3-Sigma } \\
\text { standard deviation }(\mathrm{AD})\end{array}$} \\
\hline & & & from & to & $\%$ & from & to & $\%$ \\
\hline OxA-33104 & $437 \pm 28$ & 2014 Ind 162 L Femur (Human) & 1420 & 1608 & 95.4 & 1410 & 1620 & 99.7 \\
\hline OxA-33105 & $436 \pm 29$ & 2014 Ind 176 L Tibia (Human) & 1420 & 1610 & 95.4 & 1409 & 1623 & 99.7 \\
\hline OxA-33304 & $422 \pm 24$ & 2014 Ind 246 Rib (Human) & 1433 & 1607 & 95.4 & 1424 & 1619 & 99.7 \\
\hline OxA-35066 & $376 \pm 23$ & 2014 Ind 103 Humerus (Human) & 1447 & 1630 & 95.4 & 1441 & 1635 & 99.7 \\
\hline OxA-35067 & $335 \pm 23$ & 2014 Ind 171 Femur (Human) & 1480 & 1640 & 95.4 & 1456 & 1645 & 99.7 \\
\hline OxA-35080 & $350 \pm 23$ & 2014 Ind 210 Femur (Human) & 1460 & 1635 & 95.4 & 1452 & 1641 & 99.7 \\
\hline OxA-35081 & $645 \pm 23$ & 2014 With Ind 74 (Ovis/Capra) & 1285 & 1392 & 95.4 & 1278 & 1400 & 99.7 \\
\hline OxA-35082 & $374 \pm 23$ & 2014 With Ind 216 (Ovis/Capra) & 1448 & 1630 & 95.4 & 1442 & 1635 & 99.7 \\
\hline
\end{tabular}

the Cantabrian coast, with the remaining $10 \%$ from the interior of the country (Pérez-Mallaína 2005).

Food on board ship included ship's biscuits, wine, oil, vinegar, water, salted meat and fish, broad beans, chickpeas, rice, salt and cheese, as well as any fish the sailors caught for themselves (Hamilton 1929; Pérez-Mallaína 2005; Taylor 1922). The masters' food also included the occasional roast chicken as well as dried and preserved fruits. Estimates suggest that the rations would have been sufficient in terms of calories and protein, but insufficient in terms of water and vitamins (Hamilton 1929; PérezMallaína 2005; Hayes et al. 2019). However, rations were often cut at short notice, and sometimes stewards would hoard food for their own benefit (Hamilton 1929; PérezMallaína 2005; Hayes et al. 2019).

Gibraltar's jurisdiction included the town as well as some $1,500 \mathrm{~km}^{2}$ of the surrounding countryside (the Campo de Gibraltar), which provided fields for farming and livestock (Pérez-Mallaína 2005). However, historical evidence suggests that ships provisioned in Seville relied upon food imported from further afield, including Flanders, the Canaries and Ireland (Hamilton 1929). We must bear in mind, therefore, that while food would have been produced in the Campo de Gibraltar region, it is also possible that a proportion of the food used to supply ships was imported from much further afield. Food was more expensive in the Indies than in Spain, so ships were provisioned for the entire voyage before departing, although extra supplies would have been procured en route when necessary (Hamilton 1929). The food eaten on board ship, therefore, would have shown some isotopic variability dependent upon where it was grown or raised.

\section{Geological background}

Understanding the geology of the region is important for interpreting the human ${ }^{87} \mathrm{Sr} /{ }^{86} \mathrm{Sr}$ data (Fig. 1). Gibraltar is a
$6 \mathrm{~km}^{2}$ peninsula, dominated by the $424 \mathrm{~m}$-high Rock of Gibraltar, a partly overturned mass of Early Jurassic dolomitic limestone. Gibraltar is part of the Betic Cordillera of southern and southeastern Spain, which formed as a result of interaction between the African Plate and Iberia. It consists of four parts: the Internal Betics along the coast (metamorphosed basement rocks from prior to the Miocene), the External Betics inland (Triassic Mesozoic to Miocene deposits), the Flysch units in the far south (the Campo de Gibraltar - a prism accreted from terrigenous deposits formed in the Oligocene, and likely the place from which most food was procured for Gibraltar town), and a foreland basin (the Guadalquivir Basin which contains Neogene to Quaternary aged material) (Rodriguez-Vidal et al. 2004; Alonso-Chaves et al. 2004).

\section{Isotope background}

Isotope analysis is a technique that can be used to provide information concerning diet and mobility. Based on the premise that 'you are what you eat', chemical differences in food and drink consumed during life are reflected in one's skeleton, and it is possible to infer information about past lifeways (Lee-Thorp 2008).

\section{Diet}

Carbon atoms in collagen largely reflect the protein component of the diet, while carbon atoms in tooth enamel reflect the whole diet (Ambrose and Norr 1993; Tieszen and Fagre 1993; Howland et al. 2003; Jim et al. 2006). Nitrogen is only present in the protein component of diet and therefore $\delta^{15} \mathrm{~N}$ values are solely reflective of protein consumed during life. Bone collagen is formed over many years and reflects an average of the diet over this period (Hedges et al. 2007). Dentine collagen and enamel carbonate reflects diet over the time of tooth 


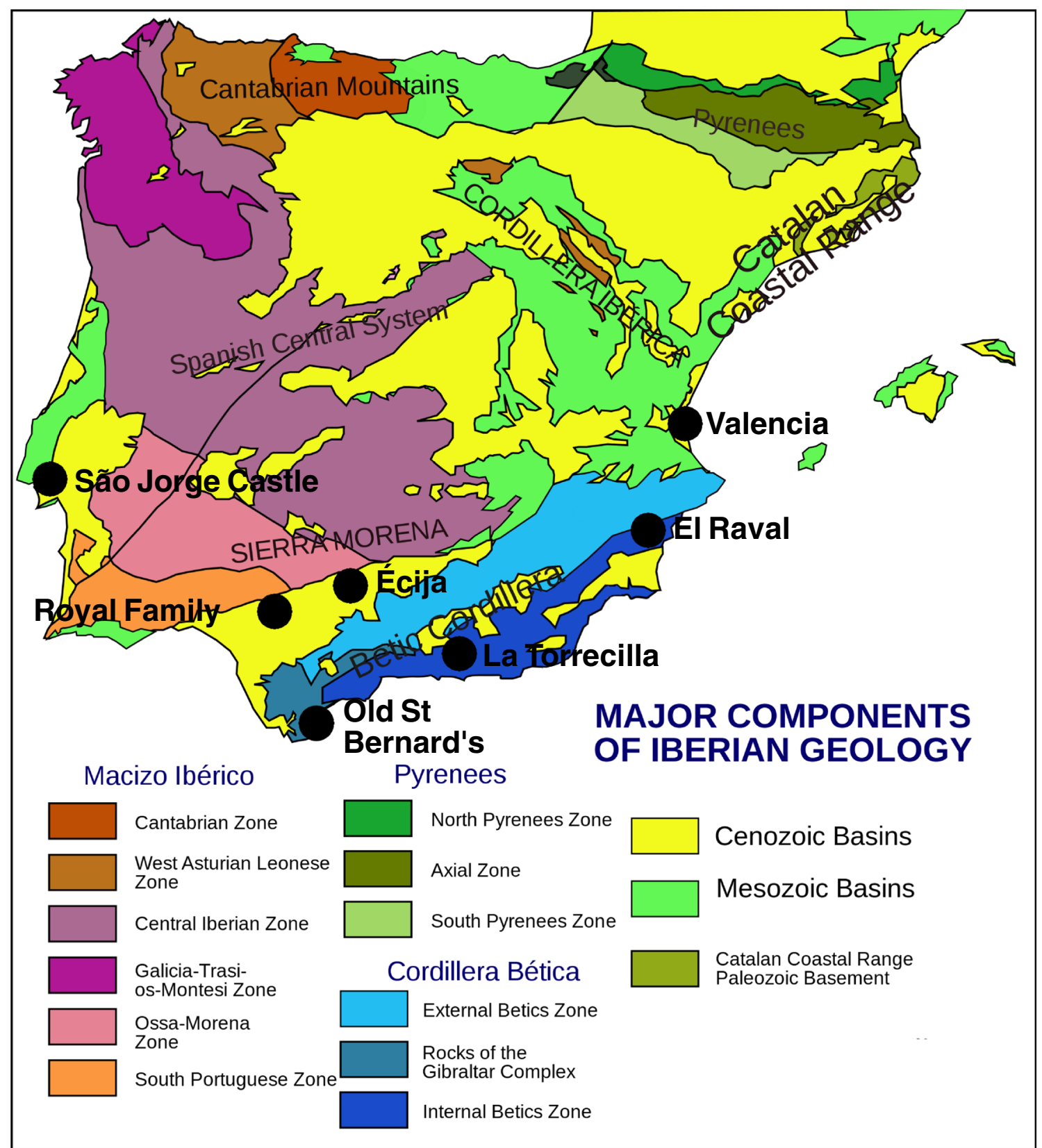

Fig. 1 Simplified geological map of Iberia showing the location of Gibraltar and other sites mentioned in the text (modified from Wikipedia contributors (2019) licenced under CC BY-SA 3.0)

formation (a number of years during development; Gustafson and Koch 1974; AlQahtani et al. 2010; Brickley et al. 2020).

$\delta^{13} \mathrm{C}$ values can be used to distinguish between plants that use different photosynthetic pathways, $\mathrm{C}_{3}$ and $\mathrm{C}_{4}$ (Vogel and Van der Merwe 1977). Most plants use the $C_{3}$ pathway, including wheat, barley, rice and potatoes, while economically important $\mathrm{C}_{4}$ plants are millet, sorghum, sugarcane and maize. $\delta^{13} \mathrm{C}$ values can also be used to distinguish between marine and terrestrial foodchains, because the ocean and the atmosphere have different $\delta^{13} \mathrm{C}$ values (Schoeninger and DeNiro 1984).

Collagen $\delta^{15} \mathrm{~N}$ values reflect the proportion of animal protein consumed during life, with the $\delta^{15} \mathrm{~N}$ value increasing by 3 to 5\%o per trophic level (Schoeninger and DeNiro 1984; O'Connell and Hedges 1999; Bocherens and Drucker 2003; Hedges and Reynard 2007). Because aquatic ecosystems tend to have longer foodchains than terrestrial ones, people who consume (freshwater or marine) fish tend to have high $\delta^{15} \mathrm{~N}$ values (Schoeninger and DeNiro 1984). People with diets based upon marine foods are characterised by having high $\delta^{13} \mathrm{C}$ and high $\delta^{15} \mathrm{~N}$ values.

Collagen $\delta^{13} \mathrm{C}$ and $\delta^{15} \mathrm{~N}$ values are relatively insensitive to minor dietary components, and it is estimated that $20 \%$ of the protein consumption must derive from an isotopically distinct source in order for it to be detectable isotopically (Hedges 
2003). When conducting stable isotope analyses on human populations, it is necessary to sample contemporaneous fauna wherever possible, as the environmental isotopic ratios at the base of the foodchain vary through space and time (Stevens and Hedges 2004).

\section{Mobility}

Tooth enamel $\delta^{18} \mathrm{O}$ and ${ }^{87} \mathrm{Sr} /{ }^{86} \mathrm{Sr}$ values reflect the food and water consumed during the time of tooth mineralisation (Harrison and Katzenberg 2003). Enamel $\delta^{18} \mathrm{O}$ values in tooth enamel are derived from consumed water and normally reflect the isotopic value of the local precipitation (Gat 1971; Gat and Dansgaard 1972). $\delta^{18} \mathrm{O}$ values in precipitation vary geographically and temporally, largely due to Rayleigh fractionation (see Sharp 2007). Individuals who, during the time of tooth formation, consumed water with a $\delta^{18} \mathrm{O}$ value notably different from that of the precipitation where they are buried, are identified as non-local. In practice, non-local individuals are often identified through statistical analysis of the dataset, as determining a local value for precipitation and calculating drinking water values from tooth enamel values is not straightforward (see Lightfoot and O'Connell 2016 and references therein).

Tooth enamel ${ }^{87} \mathrm{Sr} /{ }^{86} \mathrm{Sr}$ values in tooth enamel largely reflect the underlying geology from which the individual's food was procured (Ericson 1985). Different rocks are characterised by different ${ }^{87} \mathrm{Sr} /{ }^{86} \mathrm{Sr}$ values (Dasch 1969). These rocks weather into soils, and the plants growing on these soils have ${ }^{87} \mathrm{Sr} /{ }^{86} \mathrm{Sr}$ ratios that reflect the geology (Hurst and Davis 1981). In coastal areas, plants may also incorporate strontium from seawater which has an ${ }^{87} \mathrm{Sr} /{ }^{86} \mathrm{Sr}$ ratio of c. 0.7092 (see Montgomery et al. 2007). Animals then eat these plants and incorporate some of this strontium into their skeleton (Comar et al. 1957; Tootes and Voorhies 1965). The ${ }^{87} \mathrm{Sr} /{ }^{86} \mathrm{Sr}$ ratio is preserved as the strontium passes up the food chain as the mass difference between the two isotopes is relatively small (Blum et al. 2000; Flockhart et al. 2015). Individuals who, during the time of tooth formation, consumed food with a different ${ }^{87} \mathrm{Sr} /{ }^{86} \mathrm{Sr}$ ratio than that of the local environment are identified as non-local. Adequately, determining local bioavailable ${ }^{87} \mathrm{Sr} /{ }^{86} \mathrm{Sr}$ values is often problematic due to the difficulty in obtaining suitable comparative samples, particularly because modern samples may be affected by anthropogenic contamination (see, for example, Price et al. 2002; Bentley et al. 2004 and Maurer et al. 2012 for further discussion). In practice, non-local individuals are often identified through a combination of techniques including comparison to archaeological faunal data (with the proviso that some animals may themselves be non-local); comparison to geological maps with ${ }^{87} \mathrm{Sr} /{ }^{86} \mathrm{Sr}$ values either from large-scale studies (of water or geology) or collected modern samples; comparison with previously analysed human samples and statistical analysis of the dataset.

\section{Materials and methods}

\section{Sampling strategy}

Human bone samples were taken from 33 individuals, summarised in Table 2. We focused our analyses on long bones (femurs where possible), although ribs were also selected as a back-up. Collagen extraction was first attempted on all of the long bones $(n=33)$ and seven rib samples (for comparison of preservation). Five further ribs were later analysed from individuals where the long bone failed to provide suitable collagen for analysis.

Tooth samples were taken from all 33 individuals. Third molars were preferentially sampled, although second molars and premolars were sampled when suitable third molars were not available. Dentine samples were obtained from below the root-enamel junction from 32 teeth where roots were available to represent diet at the time of root formation, that is between c. 13 to 19 years for third molars, c. 7 and 14 years for second molars and c. 6 and 12 years for premolars (Gustafson and Koch 1974; AlQahtani et al. 2010; Brickley et al. 2020). Samples were obtained for carbonate isotope analysis from all teeth, while a subset of 17 teeth was selected for strontium isotope analysis. The isotopic results from the enamel samples represent the time of crown formation, that is between $c .9$ and 13 years for third molars, c. 3 and 7 years for second molars and c. 2 and 6 years for premolars (Gustafson and Koch 1974; Brickley et al. 2020). The teeth analysed for ${ }^{87} \mathrm{Sr} /{ }^{86} \mathrm{Sr}$ values were selected on the basis of their $\delta^{13} \mathrm{C}, \delta^{15} \mathrm{~N}$ and $\delta^{18} \mathrm{O}$ values in order to represent the range of data obtained in these analyses.

A small number of animal bones were found within burial contexts, and available for analysis (we note however that the radiocarbon dates suggest that some of these animals might relate to the Islamic period); 6 sheep/goat, 6 cattle, 5 pigs, 2 birds (possibly chicken; R. Madgwick pers. com.) and 3 fish (one possibly hake; J. Barrett pers. com.) were sampled for bone collagen extraction. Eight animal teeth were analysed for

Table 2 Summary of human bone collagen samples from Old St Bernard's Hospital

\begin{tabular}{llll}
\hline No. of individuals & Sex & Age* & Bone analysed \\
\hline 1 & Unknown & Adolescent & Femur \\
6 & Unknown & Adult & 5 femur, 1 humerus \\
1 & $?$ F & Adult & Rib \\
1 & Female & Adult & Femur \\
2 & $? \mathrm{M}$ & Adolescent & 1 femur, 1 rib \\
16 & ?M & Adult & 12 femur, 1 tibia, 3 rib \\
6 & Male & Adult & 5 femur, 1 rib \\
\hline
\end{tabular}

*See Online Resource 2 for further subdivisions of adult ages 
strontium isotope values ( 4 sheep/goat, 2 cattle and 2 pigs, all available teeth were sampled, regardless of species, due to the limited nature of the available material) and used to estimate the local baseline ${ }^{87} \mathrm{Sr} /{ }^{86} \mathrm{Sr}$ values. Full sample details are presented in Online Resource 2.

Due to the radiocarbon dates indicating that the site was earlier in date than expected (Pomeroy et al. 2018), human bone $(n=19)$ and teeth $(n=19$ for carbonate analysis, $n=$ 18 for dentine collagen analysis) were also analysed from Écija, a ninth to thirteenth century Islamic site in central Andalucía close to Córdoba, the former capital al-Andalus (full details in Online Resource 2). Further Écija data are also available from Inskip et al. (2019) where they have been described in full. These datasets are combined and included in the comparison to other studies section below with the data from Inskip et al. (2019).

\section{Collagen preparation}

Collagen was extracted from bone and dentine following the method described in Privat et al. (2002). All collagen samples were analysed in triplicate using a Costech elemental analyser coupled in continuous-flow mode to a Thermo Finnigan MAT253 mass spectrometer. Carbon and nitrogen stable isotope values are expressed as delta values $(\delta)$ relative to international scales (VPDB and AIR, respectively; Hoefs 2004). Repeated measurements on international and in-house standards showed that analytical error was $<0.2 \%$ o for both carbon and nitrogen.

Collagen is deemed to be of good quality if it fulfils the following criteria: an atomic $\mathrm{C}: \mathrm{N}$ ratio of 2.9 to 3.6 (De Niro 1985); a 'collagen' yield of $>1 \%$ by mass; final carbon yields of $>13 \%$ and final nitrogen yields of $>4.8 \%$ (Ambrose 1990). Eight human long bones and 4 human ribs failed to provide reliable collagen leaving reliable bone collagen results from 30 individuals from 25 long bone and 5 rib samples (for the three individuals where both long bone and rib data are available, the long bone data are reported here). Two of the 32 dentine samples failed to provide reliable collagen. The remaining 30 samples produced collagen deemed to be of good quality.

\section{Enamel carbonate preparation}

Tooth enamel was sampled for carbon and oxygen isotope analysis using a hand-held drill with a diamond bit attachment. The pre-treatment method was based on that described in Balasse et al. (2002). $0.1 \mathrm{ml}$ of $2-3 \%$ aqueous sodium hypochlorite was added per $\mathrm{mg}$ of sample. The samples were then left for $24 \mathrm{~h}$ at $4{ }^{\circ} \mathrm{C}$ before being rinsed five times with distilled water to remove the sodium hypochlorite. $0.1 \mathrm{mg}$ of acetic acid was then added per mg of sample. The samples were then left for four hours at room temperature, before the acetic acid was removed and the samples rinsed. Samples were then frozen and freeze-dried to remove any remaining liquid.

The samples were then transferred to a vial with a screw cap holding a septa and PCTFE washer to make a vacuum seal, and the samples reacted with $100 \%$ orthophosphoric acid at $90{ }^{\circ} \mathrm{C}$ using a Micromass Multicarb Sample Preparation System. The carbon dioxide produced was dried and transferred cryogenically into a VG SIRA mass spectrometer for isotopic analysis. $\delta^{13} \mathrm{C}$ and $\delta^{18} \mathrm{O}$ values were measured on the delta scale, in comparison to the international standard VPDB calibrated using the NBS19 standard (Craig 1957; Coplen 1995). Repeated measurements on international and inhouse standards show that the analytical error is better than $\pm 0.08 \%$ o for carbon and $\pm 0.10 \%$ o for oxygen.

\section{Enamel strontium preparation}

Tooth enamel samples for strontium isotope analysis were weighed into closed Teflon beakers and digested for $1 \mathrm{~h}$ at $140{ }^{\circ} \mathrm{C}$ in $65 \% 2 \mathrm{~B} \mathrm{HNO}_{3}$. The sample was then dried down and re-dissolved in $1.5 \mathrm{ml} 2 \mathrm{M} \mathrm{HNO}_{3}$ for strontium separation chemistry following the procedure described in Pin et al. (1994).

The separated strontium fraction for each sample was dried down, dissolved in $0.2 \% \mathrm{HNO}_{3}$ solution and diluted to $200 \mathrm{ppb} \mathrm{Sr}$ concentrations for analysis on a $\mathrm{Nu}$ Instruments NuPlasma high-resolution multi-collector inductively coupled plasma mass spectrometer (HR MC-ICP-MS). Analyses were referenced to bracketing analyses of NIST SRM987 using a ${ }^{87} \mathrm{Sr} /{ }^{86} \mathrm{Sr}$ normalising value of 0.710255 . All strontium isotope data were corrected for isobaric rubidium interference at 87 amu using the measured signal for ${ }^{85} \mathrm{Rb}$ and the natural ${ }^{85} \mathrm{Rb} /{ }^{87} \mathrm{Rb}$ ratio. Instrumental mass fractionation was corrected using the exponential law, measured ${ }^{86} \mathrm{Sr} /{ }^{88} \mathrm{Sr}$ ratios and a reference ${ }^{86} \mathrm{Sr} /{ }^{88} \mathrm{Sr}$ value of 0.1194 . Results for repeat analysis of an in-house carbonate reference material processed and measured with the samples from this study $\left({ }^{87} \mathrm{Sr} /{ }^{86} \mathrm{Sr}\right.$ $0.708878 ; 2$-sigma $0.000007 ; n=2$ ) are in agreement with long-term results for this in-house standard $\left({ }^{87} \mathrm{Sr} /{ }^{86} \mathrm{Sr}\right.$ $0.708911 ; 2$ sigma $0.000040 ; n=414)$.

Strontium concentration values provide a means of identifying samples with post-mortem contamination (Bentley 2006), with reported concentration values for human enamel typically between 50 and 300 ppm (e.g. Evans et al. 2012). The human data presented here all fell within this range, with the exception of GH130 (494 ppm). Faunal tissue strontium concentrations tend to exhibit a similar range, although herbivores tend to have higher concentrations than carnivores as plants are strontium rich compared with meat (Bocherens et al. 2011). Six of the faunal strontium concentration values fall between 121 and 352 ppm, while two samples have much higher values (512 and 601 ppm). These higher concentration 
values are not necessarily indicative of contamination, however, as high strontium concentration values coupled with strontium isotope values close to those of modern seawater (as is the case here) have, for example, been associated with the use of seaweed as a fertiliser and/or food source (Evans et al. 2012). Given that these concentrations are not necessarily related to contamination, we include these results in our analyses, below (but make no inferences about the use and consumption of seaweed).

\section{Statistical analyses}

Statistical analyses were performed using Rstudio version 1.0.143 for Macintosh. The data file and code are available in Online Resources 3 and 4. Outliers were identified in two ways: (1) as lying more than 1.5 times the inter-quartile range (IQR) below quartile 1 (Q1) or above quartile 3 (Q3) and (2) as lying more than 2 median absolute deviations (MAD) from the median (see Lightfoot and O'Connell 2016 and references therein for details). Unless noted otherwise, the results from these two methods agree.

\section{Results}

\section{Animal bone collagen data}

The animal bone collagen results are shown in Fig. 2 and summarised in Table 3 . The cattle, sheep/goat and pig samples have the lowest $\delta^{13} \mathrm{C}_{\text {bone }}$ and $\delta^{15} \mathrm{~N}_{\text {bone }}$ values, although one pig has a notably higher $\delta^{15} \mathrm{~N}_{\text {bone }}$ value than the other domestic animals (GHF02, $\delta^{15} \mathrm{~N}_{\text {bone }}=9.9 \%$; statistically identified as an outlier from other pigs and from domestic species combined). The three fish have the highest $\delta^{13} \mathrm{C}_{\text {bone }}$ and $\delta{ }^{15} \mathrm{~N}_{\text {bone }}$ values, compared to the other fauna. The two bird samples have different $\delta^{13} C_{\text {bone }}$ and $\delta^{15} \mathrm{~N}_{\text {bone }}$ values from each other.

\section{Human collagen data}

The human dentine collagen results are shown in Fig. 3. The data have a mean $\delta^{13} \mathrm{C}_{\text {dentine value of }-18.2 \% \text { ( }} \pm 0.8 \%$ o, $n=$ $30)$ and a mean $\delta^{15} \mathrm{~N}_{\text {dentine }}$ value of $11.3 \%$ ( $( \pm 1.7 \%$ o, $n=30)$. Both the $\delta{ }^{13} \mathrm{C}_{\text {dentine }}$ and $\delta^{15} \mathrm{~N}_{\text {dentine values have larger ranges }}$ than is typically seen within an archaeological adult human sample set, 4.4 and $7.6 \%$, respectively. When compared to the herbivore bone collagen values (i.e., the mean of the 6 cattle and 6 sheep/goat results), the human-faunal difference values range from 0.1 to $4.5 \%$ in $\delta^{13} \mathrm{C}$ values, and 3.3 to $10.8 \%$ in $\delta^{15} \mathrm{~N}$ values. Five or six outliers can be identified in the human dentine collagen data (dependent on statistical method used; outliers are listed in Table 4). When these individuals are excluded $(n=26)$, the human-faunal difference values range from 1.2 to $2.9 \%$ in carbon, and 3.3 to $7.1 \%$ in nitrogen.

The human bone collagen results (Fig. 2, Table 3) show that both the $\delta^{13} \mathrm{C}_{\text {bone }}$ and $\delta^{15} \mathrm{~N}_{\text {bone }}$ values have larger ranges than is typically seen in isotopically analysed adult human populations, 3.6 and $6.4 \%$, respectively. While several different types of bone were used in this analysis, the samples with the most extreme $\delta^{13} \mathrm{C}$ and $\delta^{15} \mathrm{~N}$ values were taken from femurs. Indeed, as the five rib, one tibia and one humerus samples fall within the range of the femur results and do not cluster together, we combine all of the human bone samples for subsequent analyses, although the difference in the period of time before death represented by these bones should be borne in mind. When compared to the herbivore isotopic values (i.e. the mean of the 6 cattle and 6 sheep/goat results), the human-faunal differences range from 0.4 to $4.0 \%$ in carbon, and 2.8 to $9.2 \%$ in nitrogen. There are five potential outliers (although only one of these is found using both methods; Table 4), and four of these individuals are also identified as outliers in the human dentine collagen data. When these individuals are excluded $(n=25)$, the human-faunal difference values range from 0.9 to $2.8 \%$ in carbon, and 2.8 to $7.1 \%$ in nitrogen.

Although sample size is small, there are no apparent differences between age classes in any of the collagen isotope data, and the two (possible) females have typical values in all isotopic systems.

When one compares the dentine and bone collagen results of each individual $(n=28)$, most values fall within $1 \%$; none of the $\delta^{13} \mathrm{C}$ values differ by more than $0.9 \%$ (Fig. 4). However, there are seven individuals whose dentine and bone collagen $\delta^{15} \mathrm{~N}$ results are greater than $1 \%$ different (listed in Table 4).

\section{Human tooth enamel carbonate data}

The human tooth enamel carbonate results are shown in Fig. 5. The data have a mean $\delta^{18} \mathrm{O}_{\mathrm{CO} 3}$ value of $-4.9 \%$ o $( \pm 0.8 \%, n$ $=33)$ and a mean $\delta^{13} \mathrm{C}_{\mathrm{CO} 3}$ value of $-12.3 \%$ o $( \pm 1.0 \%, n=33)$. The range in $\delta^{18} \mathrm{O}_{\mathrm{CO} 3}(3.2 \%)$ is typical for a dataset of this size (see Lightfoot and O'Connell 2016), while the range in $\delta^{13} \mathrm{C}_{\mathrm{CO} 3}(5.3 \%$ ) is larger than expected in an archaeological adult human dataset. Five potential outliers were identified (of which three are identified using both methods; shown in Table 4). With these outliers excluded $(n=27)$, the $\delta^{18} \mathrm{O}_{\mathrm{CO} 3}$ values range from -6.4 to $-3.1 \%$, and the $\delta^{13} \mathrm{C}_{\mathrm{CO} 3}$ values range from -12.8 to $-11.1 \%$.

\section{Enamel strontium data}

The animal ${ }^{87} \mathrm{Sr} /{ }^{86} \mathrm{Sr}$ values range from 0.708772 to 0.710245 (range $=0.001473, n=8$; Table 5). As there are no obvious 
Fig. 2 Scatter plot of bone collagen carbon and nitrogen isotope data from Old St Bernard's Hospital

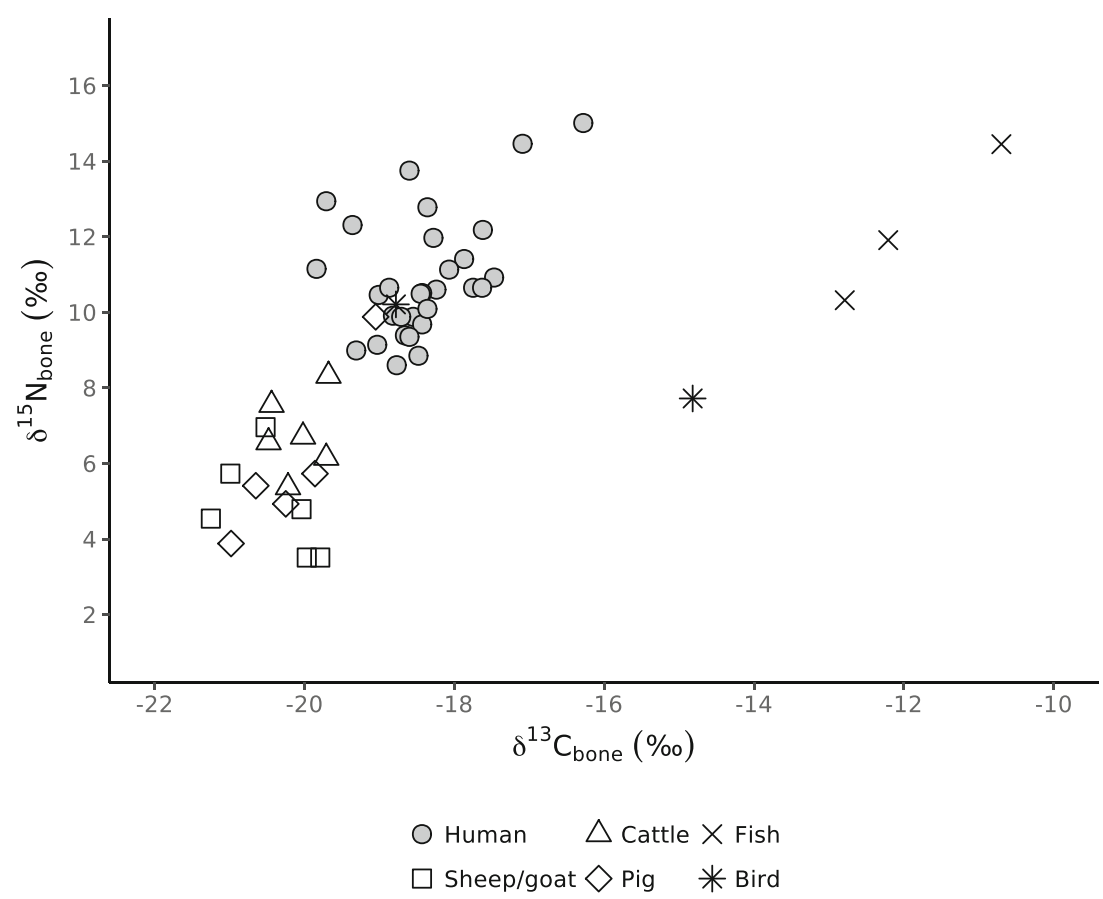

groupings or outliers within this dataset, a typical approach to defining the local range would be to use the mean plus or minus two standard deviations, which is 0.708403 to 0.710523 . However, a more robust statistical approach uses the median absolute deviation (MAD) from the median instead (see Lightfoot and O'Connell 2016). By this method, the local range is larger, and therefore more conservative in terms of identifying outliers $(0.708021$ to 0.710829$)$. Both ranges include the value for modern ocean water (c. 0.7092) and are consistent with values of Mesozoic (0.7070 to 0.7090$)$ and Cenozoic ( 0.7090 to 0.7110$)$ sediments (Voerkelius et al. 2010), consistent with Gibraltar's geology.

The human tooth enamel ${ }^{87} \mathrm{Sr} /{ }^{86} \mathrm{Sr}$ values (Fig. 6, Table 5) have a range of 0.003482 , exceeding that of the animal ${ }^{87} \mathrm{Sr} /{ }^{86} \mathrm{Sr}$ values and both of the hypothesized local ranges. It is a larger range than expected for individuals consuming a consistent diet in a single location (Lewis et al. 2017). Three human results fall outside of the hypothesized local range (GH171, GH183 and GH246) using the standard deviation method and two using the MAD method (GH171 and GH246). Considering the human results independently of the local range, six individuals (GH148, GH171, GH183, $\mathrm{GH} 243$, GH246 and GH252) are identified as outliers using the MAD method, although no outliers are identified using the IQR method.

The human ${ }^{87} \mathrm{Sr} /{ }^{86} \mathrm{Sr}$ values have a bimodal distribution (plus one clear outlier, GH246, with a value of 0.71191). Five of the identified outliers (GH148, GH171, GH183, GH243 and GH252, MAD only) have values between 0.710258 and 0.710961 and appear to represent a separate group from the main cluster (which has values between 0.708429 and 0.709443 , and includes both of the analysed female/probable female individuals, $n=11$ ). Faunal samples GHFSr05 (cattle) andGHFSr06 (sheep/goat) could also be

Table 3 Summary of human and animal bone collagen isotope data from Old St Bernard's Hospital

\begin{tabular}{|c|c|c|c|c|c|c|c|c|c|c|c|c|c|}
\hline \multirow[b]{2}{*}{ Species } & \multirow[b]{2}{*}{$\mathrm{n}$} & \multicolumn{6}{|c|}{$\delta^{13} \mathrm{C}_{\text {bone }}(\% o)$} & \multicolumn{6}{|c|}{$\delta^{15} \mathrm{~N}_{\text {bone }}(\% o)$} \\
\hline & & Mean & St Dev & IQR & Minimum & Maximum & Range & Mean & St Dev & IQR & Minimum & Maximum & Range \\
\hline Human & 30 & -18.4 & 0.7 & 0.7 & -19.8 & -16.3 & 3.6 & 10.9 & 1.6 & 2.0 & 8.6 & 15.0 & 6.4 \\
\hline Sheep/goat & 6 & -20.4 & 0.6 & 0.9 & -21.3 & -19.8 & 1.5 & 4.8 & 1.3 & 1.7 & 3.5 & 7.0 & 3.5 \\
\hline Cattle & 6 & -20.1 & 0.3 & 0.6 & -20.5 & -19.7 & 0.8 & 6.8 & 1.0 & 1.1 & 5.4 & 8.3 & 3.0 \\
\hline Pig & 5 & -20.2 & 0.7 & 0.8 & -21.0 & -19.1 & 1.9 & 6.0 & 2.3 & 0.8 & 3.9 & 9.9 & 6.0 \\
\hline Fish & 3 & -11.9 & 1.1 & 1.0 & -12.8 & -10.7 & 2.1 & 12.2 & 2.1 & 2.1 & 10.3 & 14.5 & 4.1 \\
\hline Bird & 2 & -16.8 & 2.8 & 2.0 & -18.8 & -14.8 & 4.0 & 9.0 & 1.8 & 1.2 & 7.7 & 10.2 & 2.5 \\
\hline
\end{tabular}


Fig. 3 Scatter plot of human dentine collagen plus faunal bone collagen carbon and nitrogen isotope data from Old $\mathrm{St}$ Bernard's Hospital

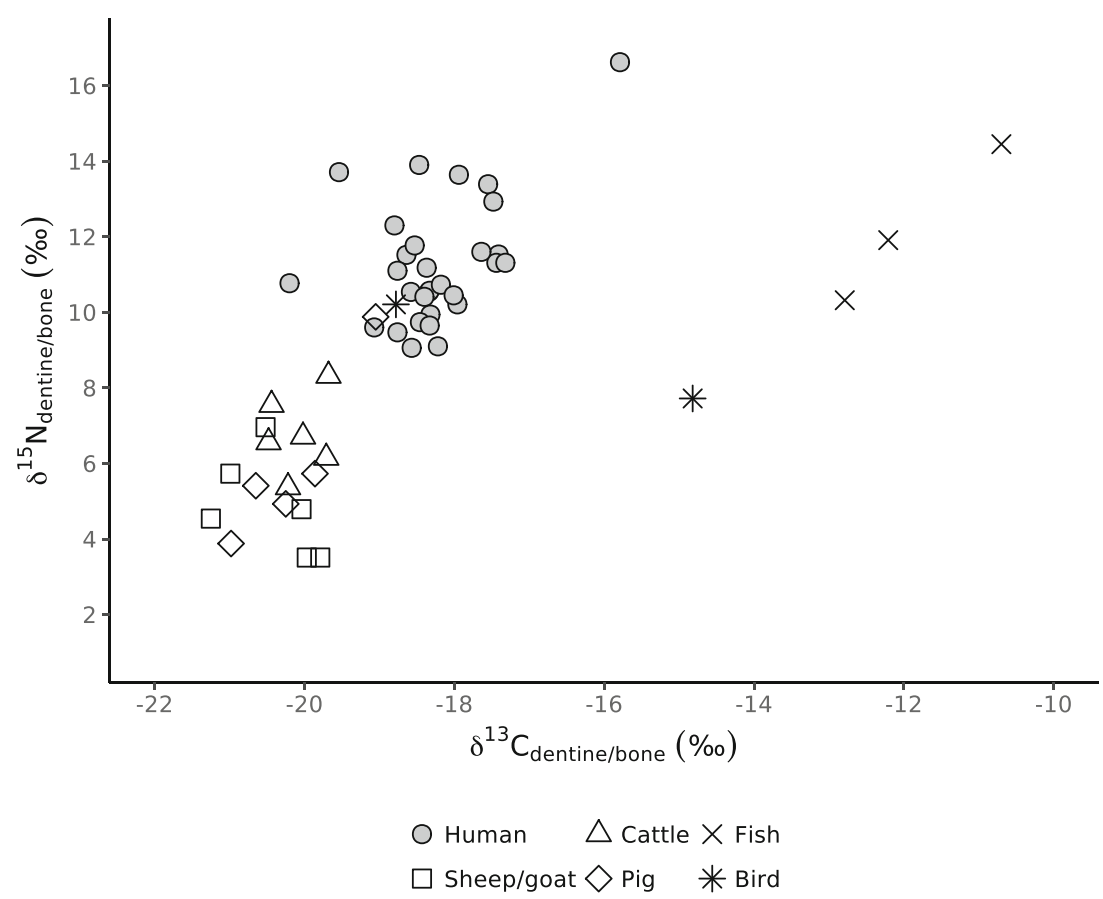

considered part of this group. It is interesting to note that of these 6 potential (human) outliers, 5 are classified as young adults, and the sixth as an adolescent.

\section{Discussion}

\section{Animal diet}

The animal isotope values fall within the ranges expected for a European ecosystem. Most sheep/goat, cattle and pigs have isotopic values indicative of the consumption of low trophic level terrestrial $\mathrm{C}_{3}$ foodstuffs, such as wheat and barley, with no indications of $\mathrm{C}_{4}$ consumption. The outlying pig (GHF09) has a $\delta^{15} \mathrm{~N}$ value (and a $\delta^{13} \mathrm{C}$ value) similar to that of the humans, suggestive of a more omnivorous diet than the other pigs. The three fish have isotopic values fitting with marine ecosystems, indicating that they are seafish (which is consistent with the identification of one of the fish as hake; J. Barrett pers. comm.). The two birds have different isotopic values; sample GHF07 has isotope values similar to the human results, which is consistent with its tentative zooarchaeological identification as chicken (R. Madgwick pers. comm.). The other bird sample (GHF08, unidentifiable to species) has much a higher $\delta^{13} \mathrm{C}$ value $(-14.8 \%$ ), closer to that of the fish than the domestic mammals. This indicates that it consumed a diet including seafood and some terrestrial food, suggesting that it was a seabird. Alternatively, this sample could also be from a chicken or other 'terrestrial' bird that was fed fish.

It remains unclear, however, if this animal dataset is strictly relevant to the human individuals studied here. Radiocarbon dating shows that at least one of the sampled animal bones pre-dates the cemetery. Furthermore, there is the compounding problem of the origins of the animals, as Gibraltar almost certainly grew and raised its food in the Campo de Gibraltar and probably also further afield (see discussion about Seville above; Hamilton 1929), and we know that these animals were not the exact ones eaten by the sailors while on board ship or, potentially, during childhood, adolescence and time spent on land between voyages. These problems must be borne in mind in the interpretation of the human results and we limit our interpretations accordingly.

\section{Human diet}

Despite the different times of life represented by dentine, femurs and ribs, the patterns seen in human dentine and bone collagen isotope values are very similar and will be discussed together. The human collagen results indicate that the people buried in Old St Bernard's Hospital had diets largely consisting of $\mathrm{C}_{3}$ plants (such as wheat and barley) and animals fed $\mathrm{C}_{3}$ plants. However, many people also consumed foods with different isotopic signatures in large enough proportions for this to be detectable isotopically, resulting in a range of diets albeit with a large common, $\mathrm{C}_{3}$, component. Comparison of the human and faunal $\delta^{15} \mathrm{~N}$ values indicates that many individuals had higher $\delta^{15} \mathrm{~N}$ values than would be expected given the terrestrial herbivore faunal isotope values (although we note that the faunal sample size is small and the range of species limited). This could suggest that they consumed high trophic level foods (such as aquatic resources), that they 


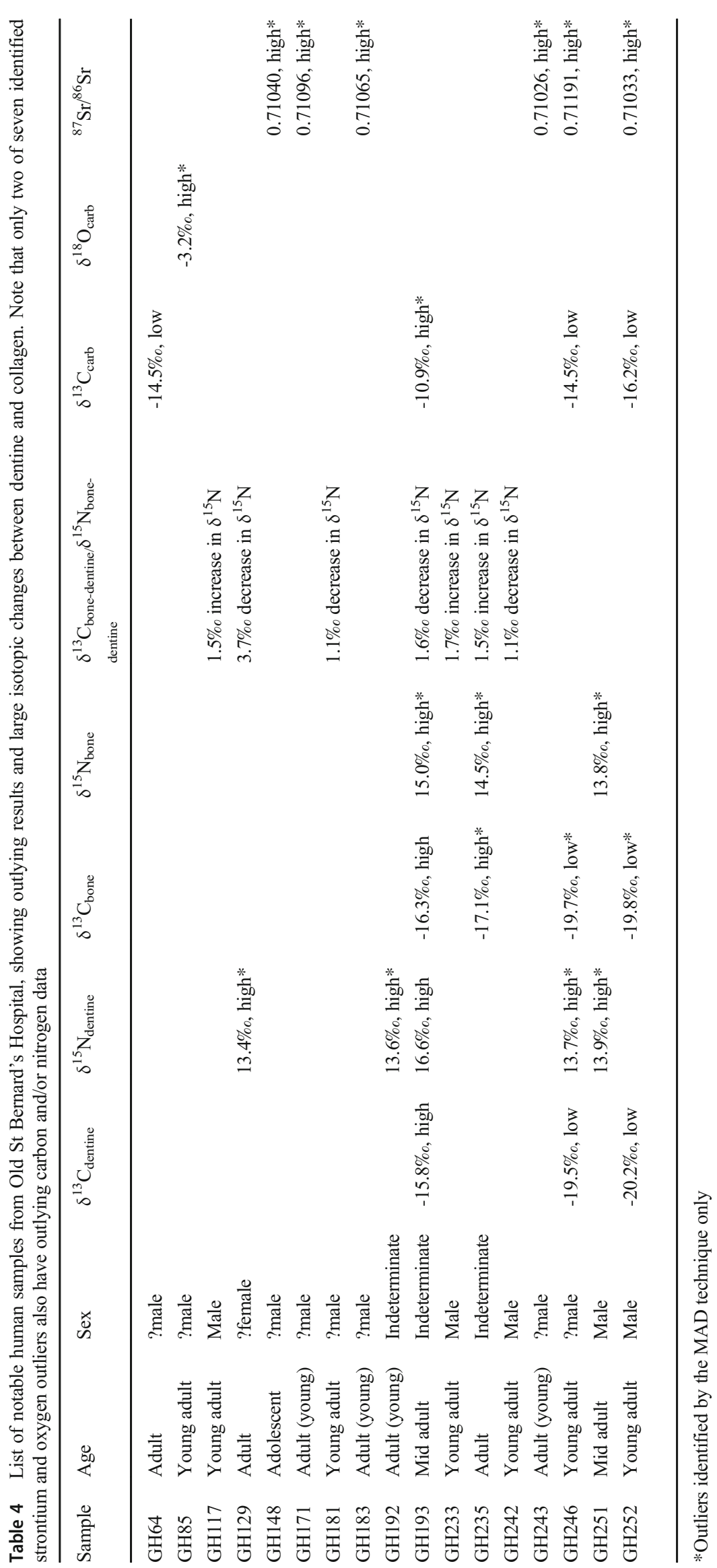


Fig. 4 Scatter plot of the difference between human dentine and bone collagen carbon and nitrogen data from Old St Bernard's Hospital

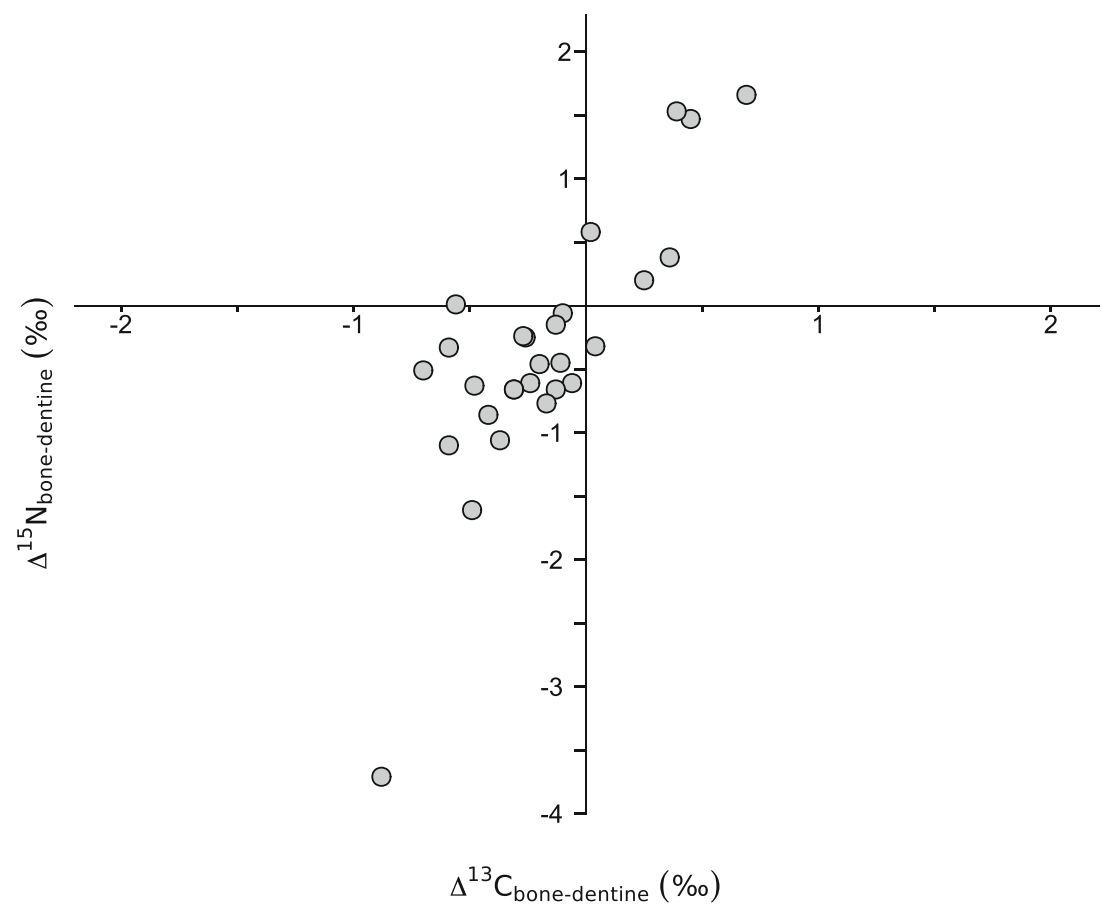

consumed a very high proportion of terrestrial animal protein in their diet or that they consumed animal protein that had higher $\delta^{15} \mathrm{~N}$ values than the domesticates analysed here. The $\delta^{13} \mathrm{C}$ human-faunal difference values suggest that the protein consumed was derived from at least two other sources: one with a higher and one with a lower $\delta^{13} \mathrm{C}$ value than the analysed domesticated animals. The people with higher than expected $\delta^{13} \mathrm{C}$ and $\delta^{15} \mathrm{~N}$ values (e.g. GH130, GH193, GH243) could have consumed a small proportion of marine resources, or a small proportion of $\mathrm{C}_{4}$ resources combined with high $\delta^{15} \mathrm{~N}$ baseline values or a high proportion of animal protein (with the exception of GH193 dentine, whose isotopic values are so high that marine consumption is the only plausible explanation). Three individuals (GH64 ${ }_{\text {bone }}, \mathrm{GH} 246, \mathrm{GH} 252$ ) have relatively low $\delta^{13} \mathrm{C}$ values which suggest the consumption of either freshwater fish with low $\delta^{13} \mathrm{C}$ values (unfortunately no freshwater fish were available for sampling to test this hypothesis) or terrestrial $C_{3}$ resources with lower baseline $\delta^{13} \mathrm{C}$
Fig. 5 Scatter plot, with marginal histograms, of human enamel carbonate carbon and oxygen isotope data from Old $\mathrm{St}$ Bernard's Hospital

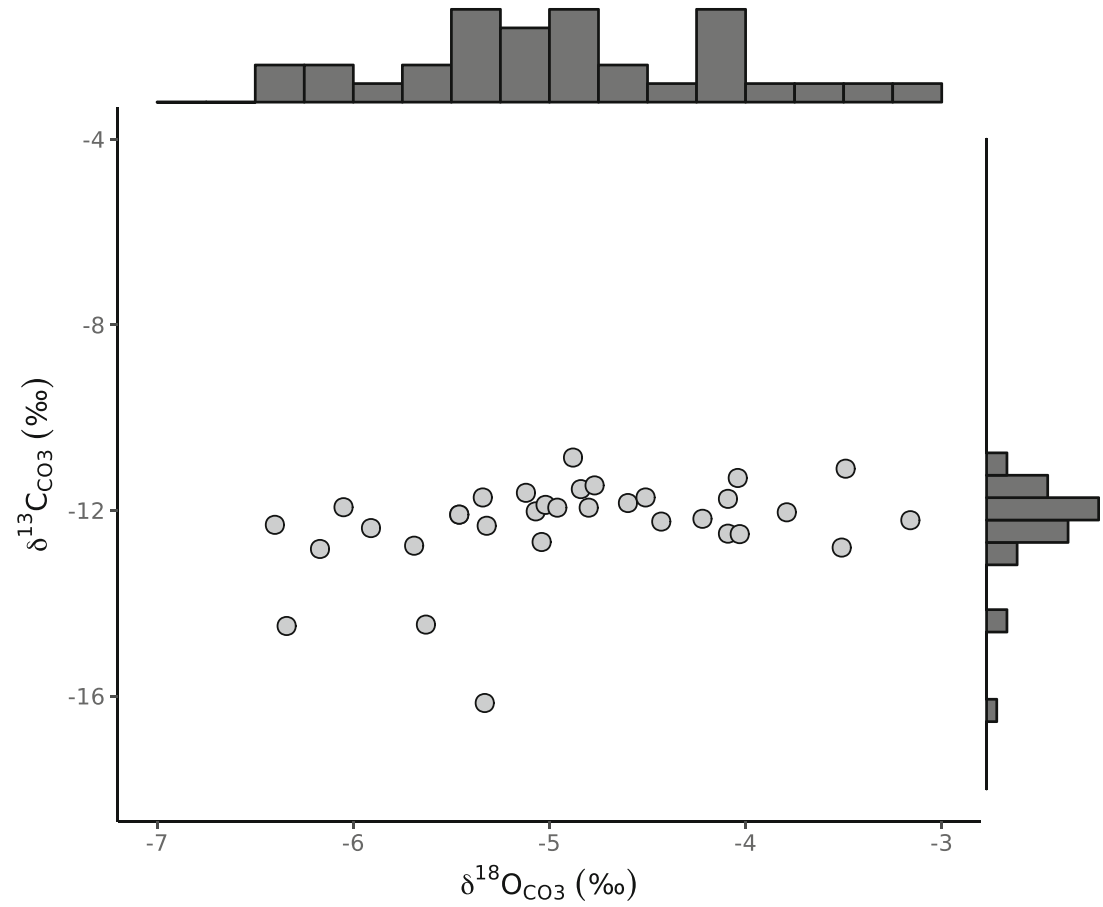


Table 5 Summary of enamel strontium data from Old St Bernard's Hospital

\begin{tabular}{|c|c|c|c|c|c|c|c|}
\hline \multirow[b]{2}{*}{ Species } & \multirow[b]{2}{*}{$\mathrm{n}$} & \multicolumn{6}{|l|}{${ }^{87} \mathrm{Sr} /{ }^{86} \mathrm{Sr}$} \\
\hline & & Mean & St Dev & IQR & Minimum & Maximum & Range \\
\hline Human & 17 & 0.70966 & 0.00093 & 0.00126 & 0.70843 & 0.71191 & 0.00348 \\
\hline Sheep/goat & 4 & 0.70943 & 0.00072 & 0.00108 & 0.70877 & 0.71025 & 0.00147 \\
\hline Cattle & 2 & 0.70956 & 0.00062 & 0.00044 & 0.70913 & 0.71000 & 0.00087 \\
\hline Pig & 2 & 0.70942 & 0.00000 & 0.00000 & 0.70942 & 0.70943 & 0.00000 \\
\hline
\end{tabular}

values than the fauna analysed here. The $\delta^{15} \mathrm{~N}$ values of $\mathrm{GH}_{6} 4_{\text {bone }}$ and GH246 would suggest the former explanation, while those of GH252 would suggest the latter. Finally, there are some individuals (e.g. GH192 and GH251) whose $\delta^{15} \mathrm{~N}$ values are higher than expected but whose $\delta^{13} \mathrm{C}$ values are typical. They may have consumed a very high proportion of local animal protein, a combination of marine and, the previously hypothesised, low $\delta^{13} \mathrm{C}$ resources, foods with a high $\delta^{15} \mathrm{~N}$ baseline value, or potentially even a different riverine system with similar $\delta^{13} \mathrm{C}$ values to the terrestrial fauna analysed here.

The carbonate carbon data represent the whole diet, rather than being biased towards the protein component, and may therefore serve to eliminate some of the potential diets hypothesised above. Compared to the collagen carbon datasets, the range in $\delta^{13} \mathrm{C}_{\mathrm{CO}}$ is remarkably small $(0.5 \%$, with outliers excluded). We can therefore infer that most people consumed diets with $\mathrm{C}_{3}$ food sources dominating the carbohydrate component of that diet and exclude the direct consumption of $\mathrm{C}_{4}$ resources on any significant scale. Three individuals (GH64, GH246 and GH252) have low $\delta^{13} \mathrm{C}_{\mathrm{CO}}$ values identified as outlying and low $\delta^{13} \mathrm{C}_{\text {coll }}$ values. Both the consumption of freshwater fish with low $\delta^{13} \mathrm{C}$ values and the consumption of terrestrial food with low baseline $\delta^{13} \mathrm{C}$ values (i.e. food sourced from a different location to that which was consumed by the majority of the analysed individuals) could cause these low human $\delta^{13} \mathrm{C}$ values. While it is difficult to pinpoint the exact cause of low terrestrial $\delta^{13} \mathrm{C}$ baseline values, possible explanations include soil type (Boulden 2016), a more closed environment (i.e. the canopy effect; van der Merwe and Medina 1991) and higher water availability (Condon et al. 1992).

In summary, human diet at this site was based upon $\mathrm{C}_{3}$ food chains, however, many people consumed food that was isotopically different to the analysed domesticates in high enough proportions for it to be detected. These 'additional' food sources are currently difficult to firmly establish, but they included at least two isotopically different resources, likely marine foods and terrestrial $\mathrm{C}_{3}$ foods from an area with an unusually low $\delta^{13} \mathrm{C}$ baseline value. There is also a fourth
Fig. 6 Scatter plot, with marginal histograms, of human enamel carbonate oxygen and strontium isotope data from Old St Bernard's Hospital

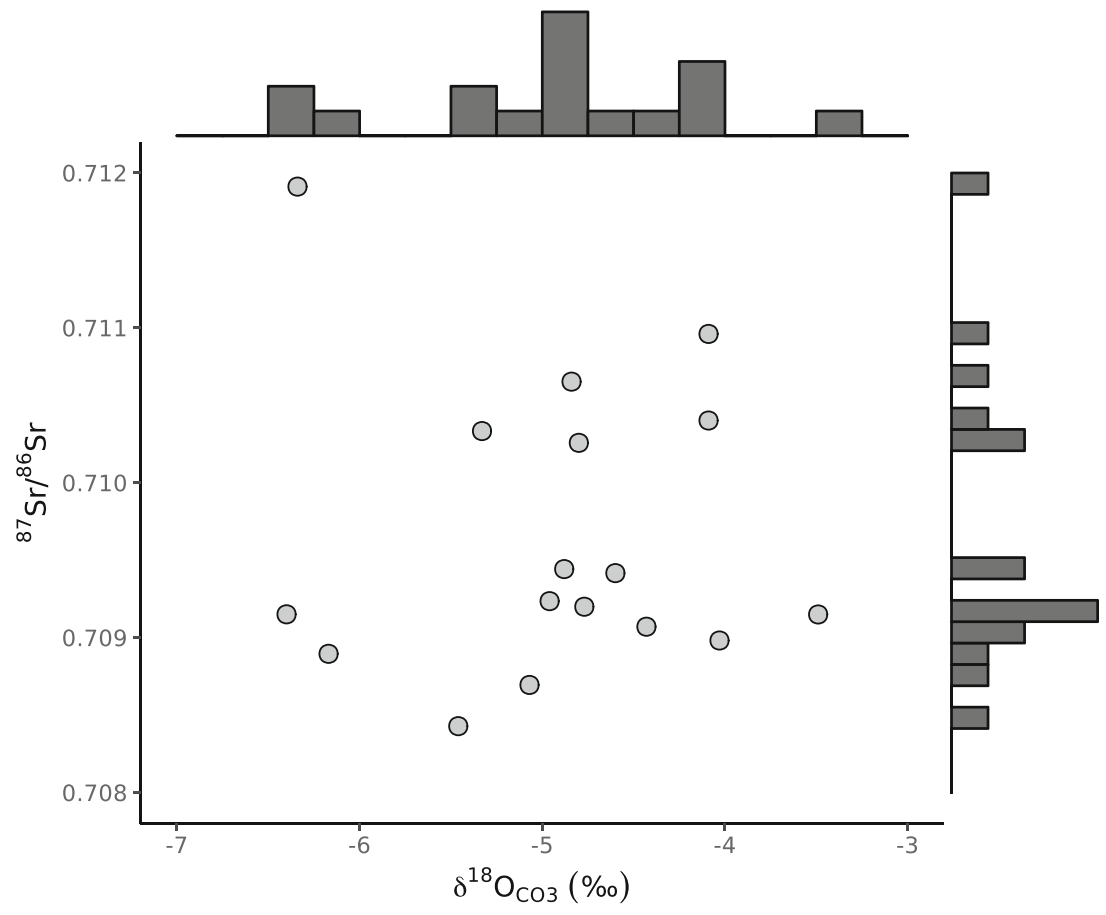


group with high $\delta^{15} \mathrm{~N}$ values who could have consumed freshwater resources and/or a very high proportion of animal protein in their diets.

While it is possible that these individuals lived together but had consistent access to isotopically different food sources, given the context of the site, it seems more likely that this reflects a population that included a substantial proportion of mariners who lived in different locations during childhood and as adolescents and adults while on land. The slight decreases in the range of both $\delta^{13} \mathrm{C}$ and $\delta^{15} \mathrm{~N}$ values between the dentine and bone collagen may reflect the impact of the sailor's homogenous diet while on board ship. As collagen reflects diet over many years (particularly in long bones as analysed here - $40 \%$ of the collagen present at age 50 could have been synthesised during adolescence; Hedges et al. 2007), one would not expect the bone collagen isotope results of sailors to be identical. Rather, the results will reflect an 'average' diet over many years, which often would include childhood, as well as time spent at sea and port, and time spent with their families. Samples taken from ribs (which are thought to represent approximately the last 10 years of life; Stenhouse and Baxter 1979) also show varied diets.

\section{Comparison to isotopic evidence for diet at other sites}

Other bone collagen data available from southern Spain largely relate to the medieval period and the widespread cultural changes that took place after the arrival of Arabs, Berbers and Islam in the 7th century. As noted elsewhere (Inskip et al. 2019), there is no clear division between Muslim and Christian communities in isotopic evidence for diet, nor does there seem to be a change in diet through time in southern Spain. Rather, these data show a wide range in values across southern Spain (Table 6, Fig. 7), reflecting both dietary differences (in particular the inclusion of $\mathrm{C}_{4}$ foodstuffs on the east coast) and variation likely due to differences in the environmental baselines between sites (compare, for example, El Raval to Benipeixcar). The Old St Bernard's individuals fall within the range of values seen in southern Spain. Notable is that the individuals with high $\delta^{15} \mathrm{~N}$ values but typical $\delta^{13} \mathrm{C}$ values (GH192, GH251) are most similar to members of the 14th century Spanish Royal Family (Jiménez-Brobeil et al. 2016). One could speculate, therefore, that these individuals consumed a very high proportion of animal protein and represent members of the nobility who served as senior officers and the like; however, there was no apparent special treatment of these individuals at burial.

In terms of naval comparisons, stable isotope results exist for skeletons excavated from the British ship, the Mary Rose, which sank in 1545 (Bell et al. 2009), and from two British 18th to 19th century naval hospitals (Roberts et al. 2012). These datasets are characterised by relatively high variability in $\delta^{13} \mathrm{C}$ and/or $\delta^{15} \mathrm{~N}$ values, with Old St Bernard's having comparable ranges, standard deviations and IQRs (Table 7). This would seem to be consistent with individuals who ate a wide range of diets suggesting that the individuals from Old $\mathrm{St}$ Bernard's might have been patients from a similarly variable broadly based population being treated at this sailors' hospital.

\section{Human mobility}

The animal ${ }^{87} \mathrm{Sr} /{ }^{86} \mathrm{Sr}$ values provide a baseline against which to compare the human dataset. We note, however, that the animals consumed in Gibraltar town were likely raised in the Campo de Gibraltar area (which encompassed 1,500 $\mathrm{km}^{2}$ of the surrounding countryside). The local baseline therefore likely reflects the Campo de Gibraltar area (i.e. the Flysch units) rather than Gibraltar itself (i.e. Early Jurassic dolomitic limestones), or perhaps a mixture of the two. Thus, people identified here as 'local' may have spent their childhood in the Campo de Gibraltar region and/or Gibraltar town itself.

Only one clear outlier emerged from the $\delta^{18} \mathrm{O}$ and ${ }^{87} \mathrm{Sr} /{ }^{86} \mathrm{Sr}$ results. GH246 (young adult, male) has a ${ }^{87} \mathrm{Sr} /{ }^{86} \mathrm{Sr}$ value of 0.711912, consistent with Middle Upper Palaeozoic sediments, or Mesozoic metamorphic rocks, as could be found in the Internal Betic zone of southern Spain (as well as other areas of Spain, Europe and North Africa). No outliers were found in the oxygen isotope data, nor are there any clear indications of patterning in the oxygen dataset.

The remaining human ${ }^{87} \mathrm{Sr} /{ }^{86} \mathrm{Sr}$ values cluster into two groups, with the individuals in the higher group (values between 0.710261 and 0.710958 ) cautiously identified as outliers. However, several of the faunal samples have similar isotope values suggesting that this group may be local. Alternatively, given that there is documentary evidence that Seville imported food from as far afield as Flanders, the Canaries and Ireland (Hamilton 1929), it is possible that these animals were imported, and the humans were from either the same place as the animals or from another location with similar isotopic values. We must also consider the possibility that these data represent a mixed signal (signifying that the individuals moved during the time of tooth formation), possibly between Gibraltar and the place where individual GH246 spent their childhood.

The remaining eleven individuals have ${ }^{87} \mathrm{Sr} /{ }^{86} \mathrm{Sr}$ values that are consistent with the archaeological fauna, large-scale strontium maps and the ${ }^{87} \mathrm{Sr} /{ }^{86} \mathrm{Sr}$ value of seawater (c. 0.7092). This may well represent a local group (noting that 'local' likely encompasses the Campo de Gibraltar) and notably this group contains both of the possible female individuals.

It is clear that there is no simple relationship between $\delta^{13} \mathrm{C}$ and $\delta^{15} \mathrm{~N}$ isotope values and ${ }^{87} \mathrm{Sr} /{ }^{86} \mathrm{Sr}$ values, and that the individuals with distinctive dietary isotope ratios (Table 4) are not necessarily the individuals identified as (possible) migrants. Four rough diet groupings were suggested above. The main diet group, who consumed a $\mathrm{C}_{3}$ diet consistent with the analysed 


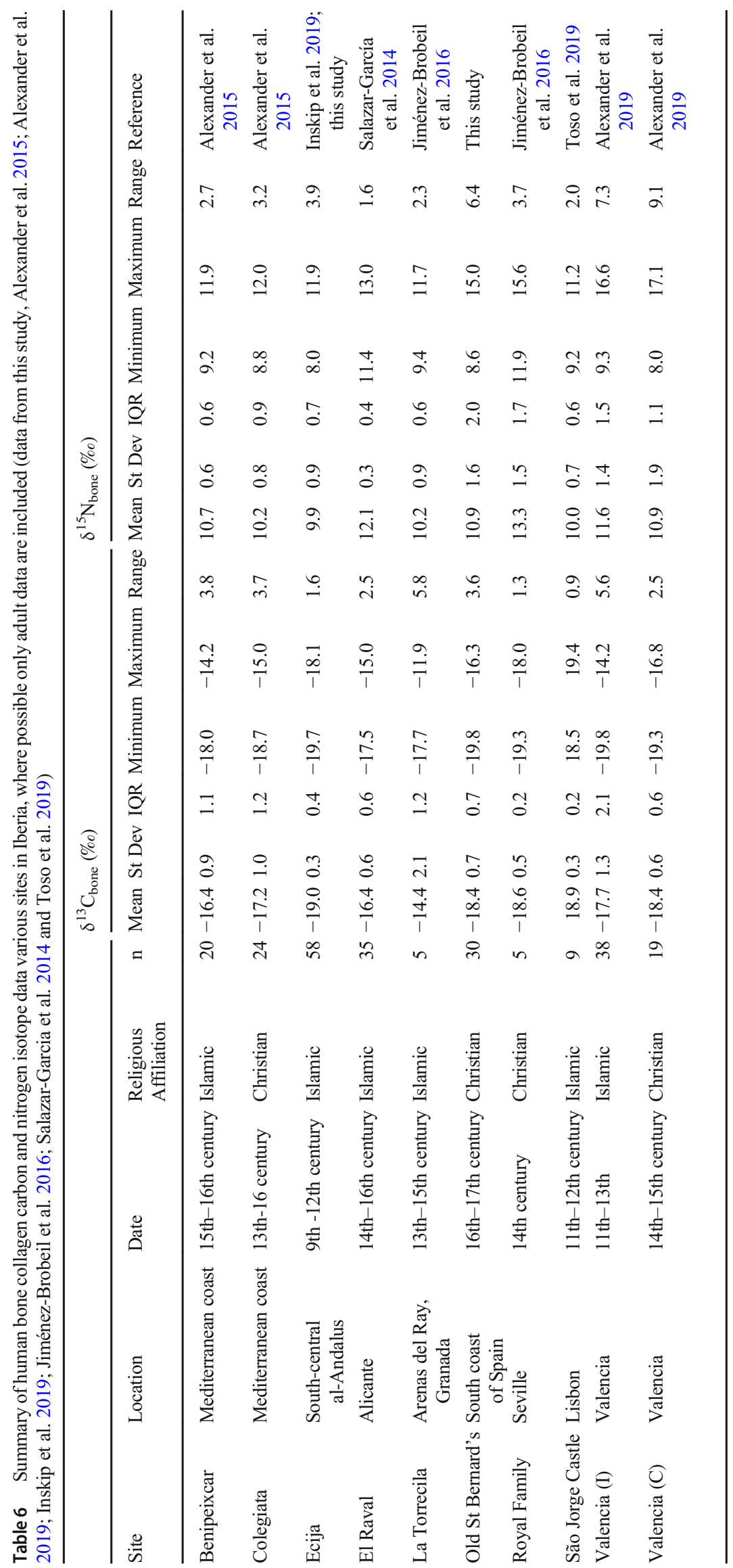


Fig. 7 Scatter plot of human bone collagen carbon and nitrogen isotope data various sites in Iberia, adult data only where possible (data from this study, Alexander et al. 2015; Alexander et al. 2019; Inskip et al. 2019; Jiménez-Brobeil et al. 2016; Salazar-Garcia et al. 2014; Toso et al. 2019)

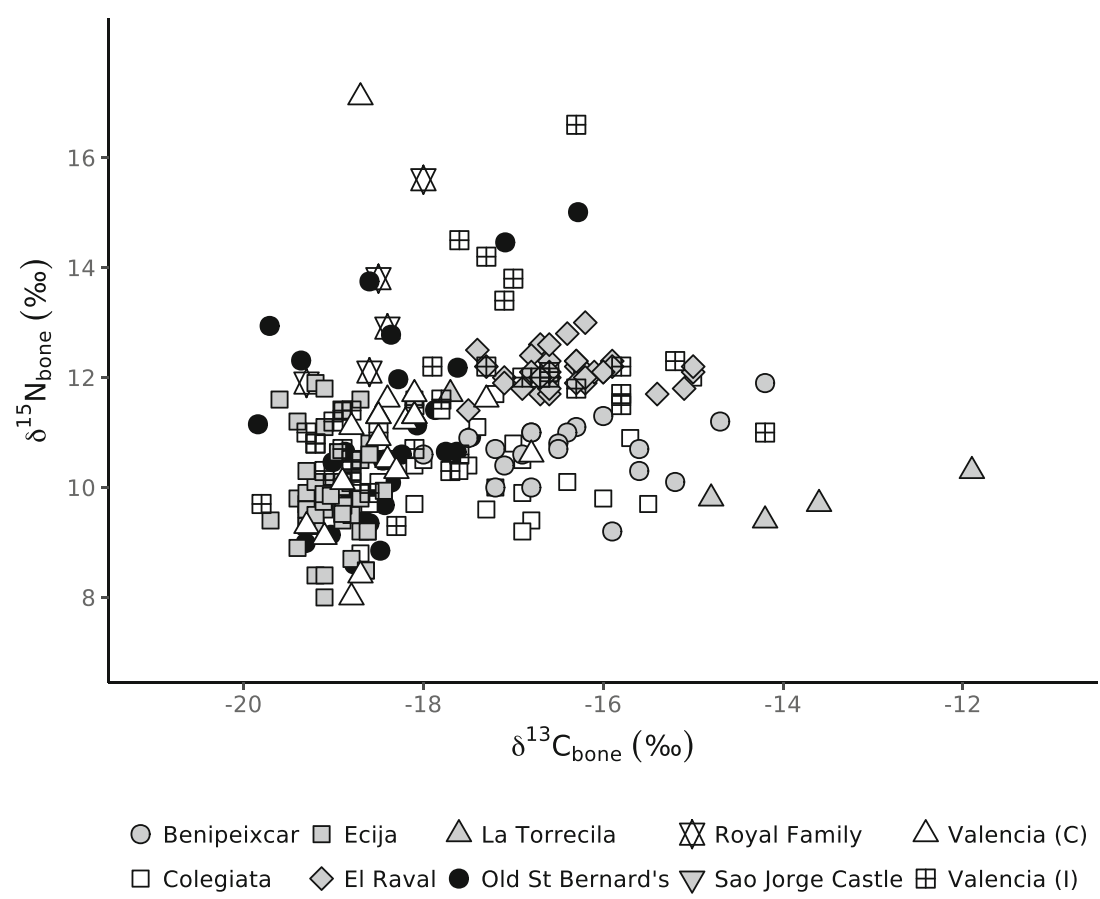

fauna, includes individuals from both the lower, 'local' strontium group (e.g. GH129 and GH142A) and the higher (?non-local) strontium group (GH148 and GH171). Two of the three individuals in the low $\delta^{13} \mathrm{C}$ value group were analysed for strontium, one of whom is the clear strontium outlier (GH246) and the other is part of the high (?non-local) strontium group (GH252). Within the group of individuals who have high $\delta^{15} \mathrm{~N}$ and high $\delta^{13} \mathrm{C}$ values, and therefore likely consumed some marine protein, are individuals who cluster with both strontium groups (GH117, GH129, GH130, GH183, GH233, GH235 and GH243). Only one of the individuals with high $\delta^{15} \mathrm{~N}$ but typical $\delta^{13} \mathrm{C}$ values was analysed for strontium (GH225); they have values that fall within the low ${ }^{87} \mathrm{Sr} /{ }^{86} \mathrm{Sr}$, local group. Overall, we are left with an impression of variation, both in terms of diet and potential homelands, and that the individuals analysed here represent a mix of people. This is consistent with the interpretation of the site as a cemetery associated with a hospital focused upon mariners.

Table 7 Summary of range of human bone collagen isotope values from naval sites (data from Roberts et al. 2012 and Bell et al. 2009)

\begin{tabular}{|c|c|c|c|c|c|c|c|}
\hline \multirow[b]{2}{*}{ Site } & \multirow[b]{2}{*}{$\mathrm{n}$} & \multicolumn{3}{|c|}{$\delta^{13} \mathrm{C}_{\text {bone }}(\% o)$} & \multicolumn{3}{|c|}{$\delta^{15} \mathrm{~N}_{\text {bone }}(\%)$} \\
\hline & & Range & St dev & IQR & Range & St dev & IQR \\
\hline Haslar & 29 & 3.4 & 0.7 & 0.8 & 2.4 & 0.6 & 0.9 \\
\hline Mary Rose & 18 & 1.1 & 0.3 & 0.4 & 4.2 & 1.0 & 1.3 \\
\hline Old St Bernard's & 30 & 3.6 & 0.7 & 0.7 & 6.4 & 1.6 & 2.0 \\
\hline Plymouth & 50 & 4.7 & 1.0 & 1.3 & 6.4 & 1.4 & 1.6 \\
\hline
\end{tabular}

\section{A cautionary tale}

The results of this study, demonstrating diversity in diet and geographic origins of the individuals, are consistent with the interpretation of the site as a mariners' hospital cemetery. This is a useful finding but we would caution against overinterpretation of the results, in that it is not possible to identify the exact diets that these individuals ate and the precise places (or even the general areas) where they grew up. There are several reasons for this from a methodological perspective. Firstly, the turnover time is such that the bone collagen of sailors would conservatively represents three or four dietary regimes - food on board ship (potentially different on outward and return journeys), food eaten in port and food eaten at 'home' which may be different between childhood and adulthood. Where such complicated life histories exist, the interpretation of bone collagen data is equally complicated.

The second methodological issue is the difficulty in establishing a relevant faunal baseline for palaeodietary analyses. This has been discussed above with specific reference to this study, but finding fauna closely associated to human remains from cemeteries is a common problem in this type of analyses.

The final methodological problem is the difficulty of identifying migrants in the absence of comparative human $\delta^{18} \mathrm{O}$ and ${ }^{87} \mathrm{Sr} /{ }^{86} \mathrm{Sr}$ data and/or a well-established strontium basemap. The problems with identifying migrants using oxygen isotope analysis have been discussed in detail elsewhere (see Lightfoot and O'Connell (2016) and references therein). Where strontium basemaps exist, coverage may be inadequate and hide small-scale variations. The alternative, the use of fauna to provide comparative data, is problematic as the fauna 
may not be 'local' (as is likely the case here) or may not represent all of the areas from which (plant and animal) food was procured.

In the case of Old St Bernard's Hospital, we have been able to interpret our data in the light of rich historical sources. In the absence of this historical data, a conservative explanation of the results would be that these were largely local people with (extremely) diverse diets, implying differential access to resources. The social inferences that could be made from this interpretation, particularly if correlations could be seen with biological sex, grave goods and so on, would lead to erroneous interpretations of the past. This demonstrates how critical it is to separate factual statements about the data from the interpretation of that dataset, as multiple interpretations are possible if one makes different assumptions about or has different expectations of the nature of the population under study. It is also critical to be explicit about what these assumptions are and what they are based upon.

\section{Conclusion}

The people buried at Old St Bernard's Hospital likely consumed varied diets throughout their lifetimes and were born in a range of different places. While all individuals consumed diets largely based on $\mathrm{C}_{3}$ plants and animals eating $\mathrm{C}_{3}$ plants, a significant degree of variation can be seen in their isotopic results. Some individuals consumed $\mathrm{C}_{3}$ foods with lower $\delta^{13} \mathrm{C}$ values than everybody else, which was likely grown/raised and consumed elsewhere. Other individuals included a notable marine component in their diet, while a few individuals had a high trophic level diet, likely freshwater fish and/or a very high proportion of animal protein. The individuals were born in a range of different places, although these homelands do not simply correlate with their various diets. This range in diets and homelands is consistent with the context of the site - a hospital in a port town, where a large number of patients were sailors, and where one would expect to find people who had grown up in different places and had different dietary regimes. The fact that these differences in diet can still be seen in the bone collagen dataset likely reflects a combination of turnover time as well as time spent on shore. The interpretation of these results benefited from the available historical information, and this has broader implications for the interpretation of isotope data elsewhere where the historical context of the site and the mobility patterns of the individuals are less well known.

Acknowledgments The authors wish to thank Catherine Kneale and James Rolfe (University of Cambridge) for their help with mass spectrometry and Carmen Esposito, Marianne Tames-Demauras and Alisa Santikarn for their help with sample preparation. Thanks also to Christel Tinguely for providing the $\mathrm{Sr}$ concentration values, and Richard Madgwick and James Barrett for faunal identification. We would also like to thank the Dorothy Garrod research group (University of Cambridge) for useful discussions of the themes in this manuscript over many years. We thank the Gibraltar National Museum support staff and volunteers for their hard work: Sioned Cox, Brielle Gafan, Kasmeen Khaira, Nuhaila Mkerref, Justin Martinez, Marie Mosquera, Jake O'Donohoe, Timothy Canessa, Gwynneth Bennet and Angela Pomeroy. We also wish to thank the two anonymous referees for their thoughtful comments on the manuscript.

Funding This research was supported by grants from the McDonald Institute for Archaeological Research at the University of Cambridge; Her Majesty's Government of Gibraltar, Ministry of Sports, Culture, Heritage, and Youth (MSCHY); and the University of Gibraltar. The work of EL was supported by the TwoRains project which was funded by the European Research Council (ERC) under the European Union's Horizon 2020 research and innovation programme (grant agreement number 648609).

\section{Compliance with ethical standards}

Conflict of interest The authors declare that they have no conflict of interest.

Open Access This article is licensed under a Creative Commons Attribution 4.0 International License, which permits use, sharing, adaptation, distribution and reproduction in any medium or format, as long as you give appropriate credit to the original author(s) and the source, provide a link to the Creative Commons licence, and indicate if changes were made. The images or other third party material in this article are included in the article's Creative Commons licence, unless indicated otherwise in a credit line to the material. If material is not included in the article's Creative Commons licence and your intended use is not permitted by statutory regulation or exceeds the permitted use, you will need to obtain permission directly from the copyright holder. To view a copy of this licence, visit http://creativecommons.org/licenses/by/4.0/.

\section{References}

Alexander MM, Gerrard CM, Gutiérrez A, Millard AR (2015) Diet, society, and economy in Late Medieval Spain: stable isotope evidence from Muslims and Christians from Gandia, Valencia. Am J Phys Anthropol 156:263-273

Alexander MM, Gutiérrez A, Millard AR, Richards MP, Gerrard CM (2019) Economic and socio-cultural consequences of changing political rule on human and faunal diets in medieval Valencia (c. fifthfifteenth century AD) as evidenced by stable isotopes. Archaeol Anthropol Sci 11(8):3875-3893

Alonso-Chaves FM, Soto JI, Orozco M, Kilias AA, Tranos MD (2004) Tectonic evolution of the Betic Cordillera: an overview. Bull Geol Soc Greece 36:1598-1607

AlQahtani SJ, Hector MP, Liversidge HM (2010) Brief communication: The London atlas of human tooth development and eruption. Am J Phys Anthropol 142(3):481-490

Ambrose SH (1990) Preparation and characterization of bone and tooth collagen for isotopic analysis. J Archaeol Sci 17(4):431-451

Ambrose SH, Norr L (1993) Isotopic composition of dietary protein and energy versus bone collagen and apatite: purified diet growth experiments. In: Lambert J, Grupe G (eds) Prehistoric human bone: Archaeology at the molecular level. Springer-Verlag, New York, pp 1-37

Balasse M, Ambrose SH, Smith AB, Price TD (2002) The seasonal mobility model for prehistoric herders in the South-western Cape of 
South Africa assessed by isotopic analysis of sheep tooth enamel. $J$ Archaeol Sci 29(9):917-932

Ballesta Gómez JM (2008) Gibraltar, Siglo XVII: Habitat, Habitos y Habitantes. Almoraima 36:199-211

Bell LS, Lee Thorp JA, Elkerton A (2009) The sinking of the Mary Rose warship: a medieval mystery solved. J Archaeol Sci 36:166-173

Benady S (1994) The civil hospital and epidemics in Gibraltar. Gibraltar Books Ltd., Gibraltar

Bentley RA (2006) Strontium isotopes from the Earth to the archaeological skeleton: a review. J Archaeol Method Theory 13(3):135-187

Bentley RA, Price TD, Stephan E (2004) Determining the 'local' ${ }^{87} \mathrm{Sr} /{ }^{86} \mathrm{Sr}$ range for archaeological skeletons: a case study from Neolithic Europe. J Archaeol Sci 31:365-375

Blum JD, Taliaferro EH, Weisee MT, Holmes RT (2000) Changes in Sr/ $\mathrm{Ca}, \mathrm{Ba} / \mathrm{Ca}$ and ${ }^{87} \mathrm{Sr} /{ }^{86} \mathrm{Sr}$ ratios between trophic levels in two forest ecosystems in the northeastern U.S.A. Biogeochemistry 49:87-101

Bocherens H, Drucker D (2003) Trophic level isotopic enrichment of carbon and nitrogen in bone collagen: case studies from recent and ancient terrestrial ecosystems. Int J Osteoarchaeol 13(1-2):46-53

Bocherens H, Brinkman DB, Dauphin Y, Mariotti A (2011) Microstructural and geochemical investigations on Late Cretaceous archosaur teeth from Alberta, Canada. Can J Earth Sci 31:783-792

Boulden, K. (2016). A bioarchaeological reassessment of land-use practices from the Neolithic to the Roman period in central southern Britain using stable isotope analysis and machine learning methods. $\mathrm{PhD}$ thesis submitted to the Department of Archaeology, University of Cambridge.

Brickley MB, Kahlon B, D’Ortenzio L (2020) Using teeth as tools: Investigating the mother-infact dyad and developmental origins of health and disease hypothesis using vitamin D deficiency. Am $J$ Phys Anthropol 171(2):342-353

Bronk Ramsey C (2017) Methods for summarizing radiocarbon datasets. Radiocarbon 59(2):1809-1833

Comar CI, Russell RS, Wasserman RH (1957) Strontium-calcium movement from soil to man. Science 126(3272):485-492

Condon AG, Richards RA, Farquhar GD (1992) The effect of variation in soil-water availability, vapor-pressure deficit and nitrogen nutrition on carbon isotope discrimination in wheat. Aust J Agric Res 43(5): 935-947

Coplen TB (1995) New IUPAC Guidelines for the reporting of stable hydrogen, carbon and oxygen isotope-ratio data. J Res Natl Instit Stand Technol 100:285

Craig H (1957) Isotopic standards for carbon and oxygen and correction factors for mass-spectromic analysis of carbon dioxide. Geochim Cosmochim Acta 12(1-2):133-149

Dasch EJ (1969) Strontium isotope in weathering profiles, deep-sea sediments, and sedimentary rocks. Geochim Cosmochim Acta 33(12): $1521-1552$

De Niro MJ (1985) Postmortem preservation and alteration of in vivo bone collagen isotope ratios in relation to paleodietary reconstruction. Nature 317:806-809

Ericson JE (1985) Strontium isotope characterization in the study of prehistoric human ecology. J Hum Evol 14:503-514

Evans JA, Chenery CA, Montgomery J (2012) A summary of strontium and oxygen isotope variation in archaeological human tooth enamel excavate from Britain. J Anal At Spectrom 27:754-764

Flockhart DT, Kyser TK, Chipley D, Miller NG, Norris DR (2015) Experimental evidence shows no fractionation of strontium isotopes (87 Sr/86 Sr) among soil, plants, and herbivores: implications for tracking wildlife and forensic science. Isot Environ Health Stud 51(3):372-381

Gat JR (1971) Comments on the stable isotope method in regional groundwater investigations. Water Resour Res 7(4):980-993
Gat JR, Dansgaard W (1972) Stable isotope survey of the fresh water occurrences in Israel and the northern Jordan Rift Valley. J Hydrol 16(3):177-211

Gozalbes Busto G (1997) El Campo de Gibraltar En La Segunda Mitad Del Siglo XVII. Almoraima 18:47-54

Gustafson G, Koch G (1974) Age estimation up to 16 years of age based on dental development. Odontologist revy 25(3):297-306

Hamilton EJ (1929) Wages and subsistence on Spanish treasure ships, 1503-1660. J Polit Econ 37(4):430-450

Harrison RG, Katzenberg MA (2003) Paleodiet studies using carbon isotopes from bone apatite and collagen: examples from Southern Ontario and San Nicolas Island, California. J Anthropol Archaeol 22:227-244

Hayes PW, Matthews JA, Allaire B, Holm P (2019) European naval diets in the sixteenth century: A quantitative method for comparative and nutritional analysis. Hist Methods: A Journal of Quantitative and Interdisciplinary History 52(4):195-212

Hedges REM (2003) On bone collagen-apatite-carbonate isotopic relationships. Int J Osteoarchaeol 13(1-2):66-79

Hedges REM, Reynard L (2007) Nitrogen isotopes and the trophic level of humans in archaeology. J Archaeol Sci 34:1240-1251

Hedges REM, Clement JG, Thomas DL, O'Connell TC (2007) Collagen turnover in the adult femoral mid-shaft: modeled from anthropogenic radiocarbon tracer measurements. Am J Phys Anthropol 133:808816

Hernández del Portillo, A. (2008) [1610-22]. Historia de Gibraltar. Algeciras: Incografic.

Hoefs J (2004) Stable isotope geochemistry. Springer Verlag, Heidelberg

Howland MR, Corr LT, Young SMM, Jones V, Jim S, Van der Merwe NJ, Mitchell AD, Evershed RP (2003) Expression of the dietary isotope signal in the compound-specific delta(13) values of pig bone lipids and amino acids. Int $J$ Osteoarchaeol 13(1-2):54-65

Hurst RW, Davis TE (1981) Strontium isotopes as tracers of airbone fly ash from coal-fired power plants. Environ Geol 3(6):363-367

Inskip SA, Carroll G, Waters-Rist A, López-Costas O (2019) Diet and food strategies in a south al-Andalsian urban environment during Caliphal period, Écija, Sevilla. Archaeol Anthropol Sci 11(8):38573874

Jim S, Jones V, Ambrose SH, Evershed RP (2006) Quantifying dietary macronutrient sources of carbon for bone collagen biosynthesis using natural abundance stable carbon isotope analysis. Br J Nutr 95:1055-1062

Jiménez-Brobeil SA, Laffranchi Z, Maroto RM, López Sánchez FA, Delgado Huertas A (2016) How royals feasted in the court of Pedro I of Castile: a contribution of stable isotope study to medieval history. J Archaeol Sci Rep 10:424-430

Lee-Thorp JA (2008) On isotopes and old bones. Archaeometry 50:925950

Lewis J, Pike AWG, Coath CD, Evershed RP (2017) Strontium concentration, radiogenic $\left({ }^{87} \mathrm{Sr} /{ }^{86} \mathrm{Sr}\right)$ and stable $\left(\delta^{88} \mathrm{Sr}\right)$ strontium isotope systematics in a controlled feeding study. STAR: Science \& Technology of Archaeological Research 3(1):45-57

Lightfoot E, O'Connell TC (2016) On the use of biomineral oxygen isotope data to identify human migrants in the archaeological record: sample variation, statistical methods and geographical considerations. PLoS One 11(4): 0153850

Maurer AF, Galer SJG, Knipper C, Beierlein L, Nunn EV, Peters D, Tütken T, Alt KW, Schöne BR (2012) Bioavailable ${ }^{87} \mathrm{Sr} /{ }^{86} \mathrm{Sr}$ in different environmental samples - effects of anthropogenic contamination and implications for isoscapes in past migration studies. Sci Total Environ 433:216-229

Montgomery J, Evans JA, Cooper RA (2007) Resolving archaeological populations with Sr-isotope mixing models. Appl Geochem 22: $1502-1514$ 
O'Connell TC, Hedges REM (1999) Investigations into the effect of diet on modern human hair isotopic values. Am J Phys Anthropol 108(4): 409-425

Pérez-Mallaína, P.E. (2005) [trans. Phillips, C.R.]. Spain's Men of the Sea. Baltimore: Johns Hopkins University Press.

Pin C, Briot D, Bassin C, Poitrasson F (1994) Concomitant separation of strontium and samarium-neodymium for isotopic analysis in silicate samples, based on specific extraction chromatography. Anal Chim Acta 298(2):209-217

Pomeroy E, Grant J, Ward D, Benady S, Reinoso del Río MC, Gutierrez López JM, Finlayson G, Finlayson S, Finlayson S, Lane K (2018) Death in the sun: the bioarchaeology of an early post-medieval hospital in Gibraltar. Post-Medieval Archaeol 20(1):1-17

Price TD, Burton JH, Bentley RA (2002) The characterization of biologically available strontium isotope ratios for the study of prehistoric migration. Archaeometry 44:117-135

Privat KL, O'Connell TC, Richards MP (2002) Stable isotope analysis of human and faunal remains from the Anglo-Saxon cemetery at Berinsfield, Oxfordshire: dietary and social implications. $J$ Archaeol Sci 29(7):779-790

Reimer PJ, Bard E, Bayliss A, Beck JW, Blackwell PG, Bronk Ramsey C, Buck CE, Cheng H, Edwards RL, Friedrich M, Grootes PM, Guilderson TP, Haflidason H, Hajdas I, Hatté C, Heaton TJ, Hoffmann DL, Hogg AG, Hughen KA, Kaiser KF, Kromer B, Manning SW, Niu M, Reimer RW, Richards DA, Scott EM, Southon JR, Staff RA, Turney CSM, van der Plicht J (2013) INTCAL13 and MARINE13 radiocarbon age calibration curves50,000 years cal BP. Radiocarbon 55(4):1869-1887

Roberts P, Weston S, Wild B, Boston C, Ditchfield P, Shortland AJ, Pollard AM (2012) The men of Nelson's navy: a comparative stable isotope dietary study of late 18th century and early19th century servicemen from Royal Naval hospital burial grounds at Plymouth and Gosport, England. Am J Phys Anthropol 148:1-10

Rodriguez-Vidal J, Caceres LM, Finlayson JC, Gracia FJ, MartınezAguirre A (2004) Neotectonics and shoreline history of the Rock of Gibraltar, southern Iberia. Quat Sci Rev 23:2017-2029

Salazar-Garcia DC, Richards MP, Nehlich O, Henry AG (2014) Dental calculus is not equivalent to bone collagen for isotope analysis: a comparison between carbon and nitrogen stable isotope analysis of bulk dental calculus, bone and dentine collagen from same individuals from the Medieval site of El Raval (Alicante, Spain). J Archaeol Sci 47:70-77
Schoeninger MJ, DeNiro MJ (1984) Nitrogen and carbon isotopic composition of bone collagen from marine and terrestrial animals. Geochim Cosmochim Acta 48:625-639

Sharp ZD (2007) Principles of stable isotope geochemistry. Prentice Hall, New Jersey

Stenhouse, M.J. and Baxter, M.S. 1979: The uptake of bomb 14C in humans. In: Berger, R. and Suess, H. (eds) Radiocarbon Dating (Berkeley: University of California Press)

Stevens RE, Hedges REM (2004) Carbon and nitrogen stable isotope analysis of northwest European horse bone and tooth collagen, 40, 000 BP-present: Palaeoclimatic interpretations. Quat Sci Rev 23(78):977-991

Taylor PS (1922) Spanish seamen in the New World during the colonial period. Hisp Am Hist Rev 5(4):631-661

Tieszen LL, Fagre T (1993) Effect of diet quality on the isotopic composition of respiratory $\mathrm{CO}_{2}$, bone collagen, bioapatite and soft tissues. In: Lambert JB, Grupe G (eds) Prehistoric Human Bone: Archaeology at the Molecular Level. Springer-Verlag, Berlin, pp $121-155$

Tootes H, Voorhies MR (1965) Strontium in fossil bones and the reconstruction of food chains. Science 149:854-855

Toso, A., Gaspar, S., Banha da Silva, R., Garcia, S. J., \& Alexander, M. (2019). High status diet and health in Medieval Lisbon: a combined isotopic and osteological analysis of the Islamic population from São Jorge Castle, Portugal. Archaeological and Anthropological Sciences, available online.

van der Merwe NJ, Medina E (1991) The canopy effect, carbon isotope ratios and foodwebs in Amazonia. J Archaeol Sci 18:249-259

Voerkelius S, Lorenz GD, Rummel S, Quétel CR, Heiss G, Baxter M, Brach-Papa C, Deters-Itzelsberger P, Hoelzl S, Hoogewerff J (2010) Strontium isotopic signatures of natural mineral waters, the reference to a simple geological map and its potential for authentication of food. Food Chem 118(4):933-940

Vogel JC, Van der Merwe NJ (1977) Isotopic evidence for early maize cultivation in New-York State. Am Antiq 42(2):238-242

Wikipedia contributors. (2019). Geology of the Iberian peninsula. In Wikipedia, The Free Encyclopedia. https://en.wikipedia.org/wiki/ Geology_of_the_Iberian_Peninsula. Accessed 10 April 2019

Publisher's note Springer Nature remains neutral with regard to jurisdictional claims in published maps and institutional affiliations. 